\title{
RECEIVED
}

MAR 131996

OSTI

OAK RIDGE NATIONAL LABORATORY

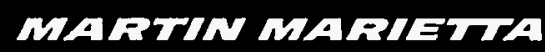

\section{Structural Thermal Tests on Advanced Neutron Source Reactor Fuel Plates}

W. F. Swinson

R. L. Battiste

G. T. Yahr

August 1995

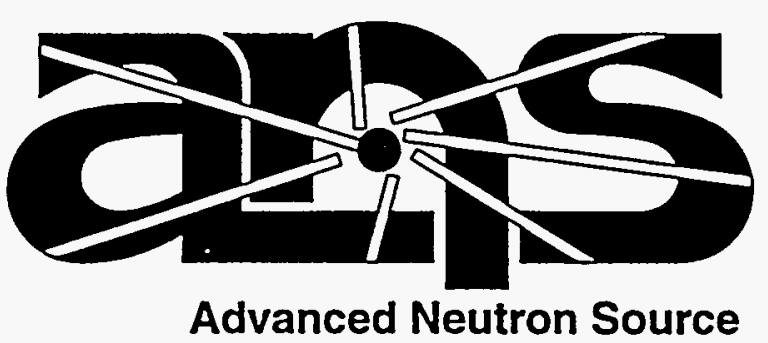


This report has been reproduced directly from the best available copy.

Available to DOE and DOE contractors from the Office of Scientific and Technical information, P.O. Box 62, Oak Ridge, TN 37831; prices available from (615) 576-8401, FTS 626-8401.

Available to the public from the National Technical Information Service, U.S. Department of Commerce, 5285 Port Royal Rd., Springtield, VA 22161.

This report was prepared as an account of work sponsored by an agency of the United States Government. Neither the United States Government nor any agency thereof, nor any of their employees, makes any warranty, express or implied, or assumes any legal liability or responsibility for the accuracy. completeness, or usefulness of any information, apparatus, product, or process disclosed, or represents that its use would not intringe privately owned rights. Reference herein to any specific commercial product, process, or service by trade name, trademark, manufacturer, or otherwise, does not necessarily consti tute or imply its endorsement, recommendation, or favoring by the United States Government or any agency thereof. The views and opinions of authors expressed herein do not necessarily state or reflect those of the United States Government or any agency thereof. 
Engineering Technology Division

\title{
STRUCTURAL THERMAL TESTS ON ADVANCED NEUTRON SOURCE REACTOR FUEL PLATES
}

\author{
W. F. Swinson \\ R. L. Battiste \\ G. T. Yahr
}

August 1995

Prepared by

OAK RIDGE NATIONAL LABORATORY

Oak Ridge, Tennessee 37831

managed by

LOCKHEED MARTIN ENERGY SYSTEMS, INC.

for the

U.S. DEPARTMENT OF ENERGY

under contract DE-AC05-84OR21400 


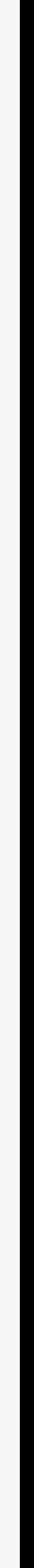




\section{CONTENTS}

LIST OF FIGURES $\ldots \ldots \ldots \ldots \ldots \ldots \ldots \ldots \ldots \ldots \ldots \ldots \ldots \ldots \ldots \ldots$

LIST OF TABLES $\ldots \ldots \ldots \ldots \ldots \ldots \ldots \ldots \ldots \ldots \ldots \ldots \ldots \ldots \ldots \ldots$

ACRONYMS AND SYMBOLS $\ldots \ldots \ldots \ldots \ldots \ldots \ldots \ldots \ldots \ldots \ldots \ldots \ldots \ldots$

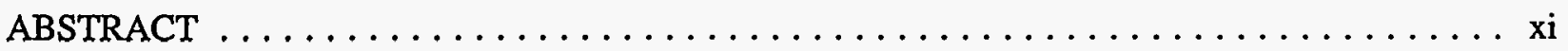

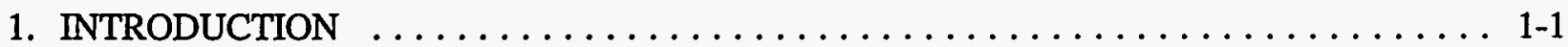

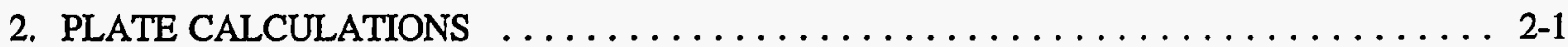

3. DESIGN AND EVALUATION OF THE EXPERIMENTAL SETUP . . . . . . . . . 3-1

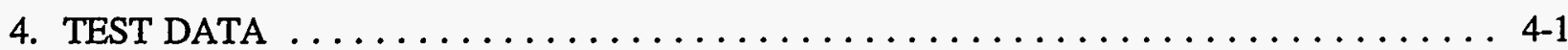

5. INTERPRETATION OF THE RESULTS $\ldots \ldots \ldots \ldots \ldots \ldots \ldots \ldots \ldots \ldots \ldots \ldots$

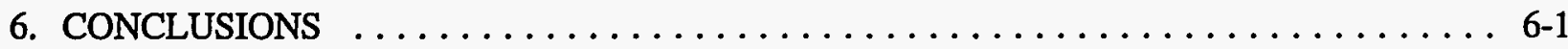

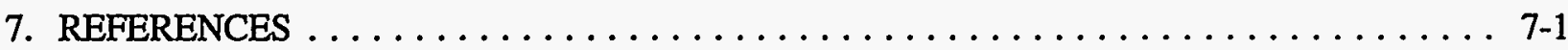




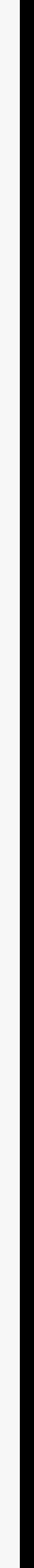




\section{LIST OF FIGURES}

Figure

$\underline{\text { Page }}$

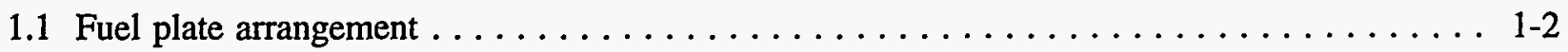

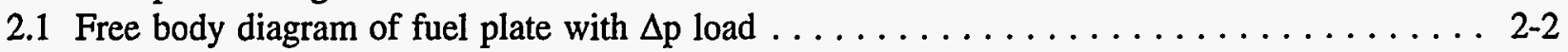

2.2 Free body diagram of fuel plate with $\Delta \mathrm{T}$ load $\ldots \ldots \ldots \ldots \ldots \ldots \ldots \ldots \ldots \ldots$

2.3 Free body diagram of longitudinal thermal forces $\ldots \ldots \ldots \ldots \ldots \ldots \ldots \ldots \ldots$

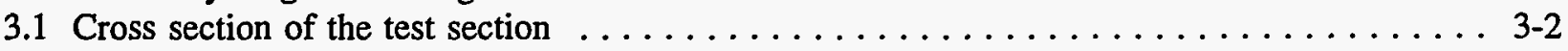

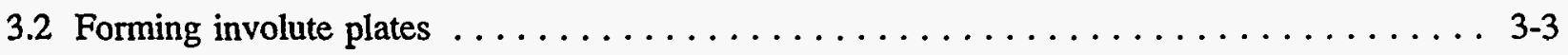

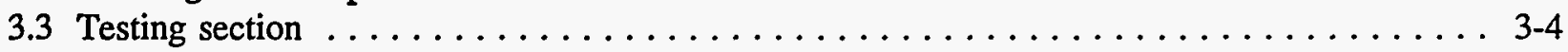

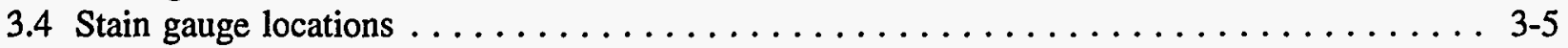

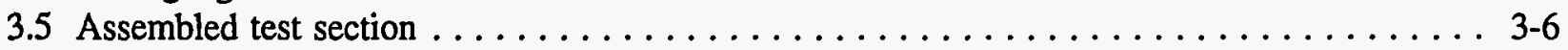

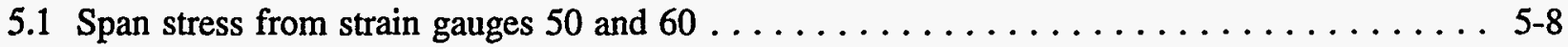

5.2 Span stress from strain gauges $5 \mathrm{i}$ and $6 \mathrm{i} \ldots \ldots \ldots \ldots \ldots \ldots \ldots \ldots \ldots \ldots \ldots$

5.3 Span stress from strain gauges 10 and $20 \ldots \ldots \ldots \ldots \ldots \ldots \ldots \ldots \ldots \ldots \ldots \ldots \ldots \ldots$

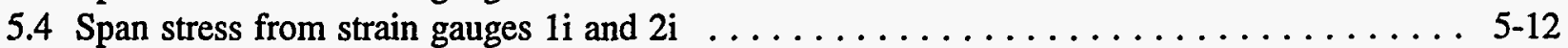

5.5 Span stress from strain gauges 30 and $40 \ldots \ldots \ldots \ldots \ldots \ldots \ldots \ldots \ldots \ldots \ldots \ldots$

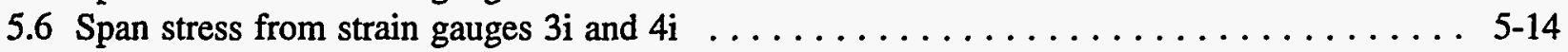




\section{LIST OF TABLES}

Table

$\underline{\text { Page }}$

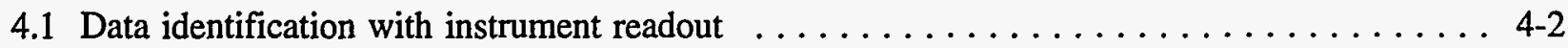

4.2 Strain gauge readings from test at $68.9 \mathrm{kPa}(10 \mathrm{psi}) \ldots \ldots \ldots \ldots \ldots \ldots \ldots \ldots \ldots$

4.3 Strain gauge readings from test at $137.9 \mathrm{kPa}(20 \mathrm{psi}) \ldots \ldots \ldots \ldots \ldots \ldots \ldots \ldots \ldots$

4.4 Strain gauge readings from test at $172.4 \mathrm{kPa}(25 \mathrm{psi}) \ldots \ldots \ldots \ldots \ldots \ldots \ldots \ldots$

4.5 Strain gauge readings from test at $206.8 \mathrm{kPa}(20 \mathrm{psi}) \ldots \ldots \ldots \ldots \ldots \ldots \ldots \ldots$

4.6 Strain gauge readings from test at $275.8 \mathrm{kPa}(40 \mathrm{psi}) \ldots \ldots \ldots \ldots \ldots \ldots \ldots \ldots$

4.7 Strain gauge readings from test at $344.7 \mathrm{kPa}(50 \mathrm{psi}) \ldots \ldots \ldots \ldots \ldots \ldots \ldots \ldots$

5.1 Corrected strain values and stress calculations for test at $68.9 \mathrm{kPa}(10 \mathrm{psi}) \ldots \ldots \ldots .2$

5.2 Corrected strain values and stress calculations for test at $137.9 \mathrm{kPa}(20 \mathrm{psi}) \ldots \ldots \ldots$

5.3 Corrected strain values and stress calculations for test at $172.4 \mathrm{kPa}(10 \mathrm{psi}) \ldots \ldots \ldots . . .5$

5.4 Corrected strain values and stress calculations for test at $206.8 \mathrm{kPa}(30 \mathrm{psi}) \ldots \ldots \ldots .5$

5.5 Corrected strain values and stress calculations for test at $275.8 \mathrm{kPa}(40 \mathrm{psi}) \ldots \ldots \ldots \ldots$

5.6 Corrected strain values and stress calculations for test at $344.7 \mathrm{kPa}(50 \mathrm{psi}) \ldots \ldots \ldots$ 


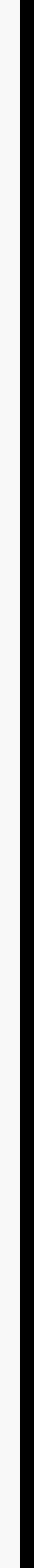




\section{ACRONYMS AND SYMBOLS}

\begin{tabular}{|c|c|}
\hline ANS & Advanced Neutron Source \\
\hline a & inner support cylinder radius \\
\hline A & area that supports the tangential and shear loads \\
\hline$A_{i, s .}$ & cross sectional area of inner support cylinder \\
\hline$A_{0, s .}$ & cross sectional area of outer support cylinder \\
\hline$A_{p l}$ & cross sectional area of plates \\
\hline $\mathrm{E}^{\mathrm{ph}}$ & modulus of elasticity \\
\hline $\mathrm{E}_{\mathrm{i} . \mathrm{s} .}$ & modulus of elasticity of inner support cylinder \\
\hline $\mathrm{E}_{\text {o.s. }}$ & modulus of elasticity of outer support cylinder \\
\hline $\mathrm{E}_{\mathrm{pl}}$ & modulus of elasticity of plates \\
\hline $\mathrm{F}_{\mathrm{i}, \mathrm{s} .}$ & average axial force in the inside support \\
\hline$F_{0 . s .}$ & average axial force in the outside support \\
\hline $\mathrm{F}_{\mathrm{pl}}$ & average axial force in the plates \\
\hline$h^{p+}$ & channel thickness \\
\hline I & area moment of inertia \\
\hline$I_{\text {i.s. }}$ & length of inside support cylinder \\
\hline $1_{0 . s .}$ & length of outside support cylinder \\
\hline $\mathrm{l}_{\mathrm{pl}}$ & length of plate \\
\hline $\mathbf{M}$ & moment in plate \\
\hline $\mathrm{M}_{\mathrm{lp}}$ & plate outer boundary moment due to pressure load \\
\hline $\mathrm{M}_{\mathrm{lt}}$ & plate outer boundary moment due to thermal load \\
\hline $\mathrm{M}_{\mathrm{op}}$ & plate inner boundary moment due to pressure load \\
\hline$M_{o t}$ & plate inner boundary moment due to thermal load \\
\hline $\mathbf{N}$ & tangent load in plate \\
\hline$N_{l p}$ & plate tangent load due to pressure load \\
\hline $\mathrm{N}_{\mathrm{ot}}$ & plate tangent load due to thermal load \\
\hline$\Delta \mathrm{p}$ & average pressure difference across a plate \\
\hline $\mathrm{T}_{\mathrm{i}, \mathrm{s} .}$ & temperature of inside support boundary \\
\hline $\mathrm{T}_{\text {o.p. }}$ & temperature of outside support boundary \\
\hline $\mathrm{T}_{\mathrm{pl}}$ & temperature of plates \\
\hline$U^{n+}$ & strain energy \\
\hline $\mathrm{V}$ & coolant flow velocity \\
\hline$V_{l p}$ & plate outer boundary shear load due to pressure load \\
\hline $\mathrm{V}_{\mathrm{lt}}$ & plate outer boundary shear load due to thermal load \\
\hline $\mathrm{V}_{\mathrm{op}}$ & plate inner boundary shear load due to pressure load \\
\hline $\mathrm{V}_{\mathrm{ot}}$ & plate inner boundary shear load due to thermal load \\
\hline$y_{r}$ & the y-coordinate projection of plate \\
\hline$\delta_{\text {i.s. }}$ & inside support longitudinal deformation from thermal load \\
\hline$\delta_{\text {o.s. }}$ & outside support longitudinal deformation from thermal load \\
\hline$\delta_{\mathrm{pl}}$ & plate longitudinal deformation from thermal load \\
\hline$\Delta \mathrm{T}$ & plate thermal load, plate temperature minus the boundary temperature \\
\hline$v$ & coolant kinematic viscosity \\
\hline$\phi$ & involute angle \\
\hline$\dot{\phi}_{1}$ & involute angle to outer boundary \\
\hline$\rho$ & coolant density \\
\hline$\sigma_{\mathrm{ax}}$ & longitudinal principal stress \\
\hline
\end{tabular}




\section{ACRONYMS AND SYMBOLS (continued)}

$\sigma_{\mathrm{Ip}}$

$\sigma_{\mathrm{It}}$

$\sigma_{\text {op }}$

$\sigma_{\text {ot }}$

span principal stress at the outer boundary from pressure load span principal stress at the outer boundary from thermal load span principal stress at the inner boundary from pressure load span principal stress at the inner boundary from thermal load 


\begin{abstract}
The thin aluminum-clad fuel plates proposed for the Advanced Neutron Source reactor are stressed by the high-velocity coolant flowing on each side of the plates and by the thermal gradients in the plates. The total stress, composed of the sum of the flow stress and the thermal stress at a point, could be reduced if the thermal loads tend to relax when the stress magnitude approaches the yield stress of the material. The potential of this occurring would be very significant in assessing the structural reliability of the fuel plates and has been investigated through experiment. The results of this investigation are given in this report.
\end{abstract}




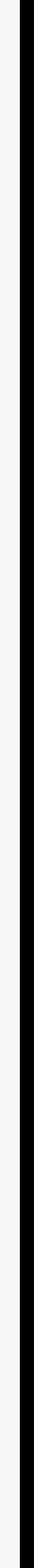




\section{INTRODUCTION}

The proposed fuel plates for the Advanced Neutron Source reactor (ANS) reactor consist of uranium silicide fuel encased in aluminum. The plates are cooled by flowing heavy water in narrow channels on each side of the thin involute-shaped plates. Figure 1.1 illustrates how the involute plates are arranged and cooled in the reactor. Thin fuel plates with different shapes such as flat or circular and with cooling through narrow channels have been used in reactor design since the 1940s. Structural failures of some of these plates have occurred and have always been cause for concern. However, calculating the structural response of these thin plates to the imposed loads has proven to be a very difficult task, mostly because of the difficulty in predicting the loads imposed by the coolant flow. The coolant flow is highly turbulent, and the flow in each channel is different, loading the plates by the different pressures generated on each side of each plate. In addition to the flow or pressure load on the plates, a thermal load is developed by the plates' being at higher temperatures than the support cylinders.

A considerable amount of effort has been expended to test and analyze the structural response of the ANS fuel plates. ${ }^{1-5}$ The work done indicates that potential yielding resulting from the induced stress in the plates is more of a concern than elastic deformation is. Therefore, an assessment of the induced stress is the principal consideration in evaluating a given plate design. However, evaluating the plates structurally by superimposing the stresses caused by the thermal load onto the stresses caused by the flow pressure load and comparing the result with the material yield stress is not necessarily the best design practice because the stresses caused by the different loads produce different effects on the plates. If a plate is loaded by pressure and starts to yield, it tends with a steady load to continue deformation until failure. However, if a plate is thermally loaded and starts to yield, only slight deformation may occur before the thermal load relaxes. Depending on the application, it is common design practice to assign different "weights" to these different load types in the design evaluation. What weights to assign the different load types is always an experience or judgment problem and is best answered through experimentation.

The ASME pressure vessel design code illustrates one example of assigning weights to different load types in design practice. The code defines primary and secondary stresses, which are best delineated by the loads that induce them, and assigns different design weights to these stresses. Primary stresses are subdivided into membrane and bending stresses and are induced by loads like pressure, which are steady or continuous even if the vessel material yields. Such loads can cause catastrophic failures. Loads that induce secondary stresses, such as some thermal loads, tend to relax when the material yield stress is reached. Assigning design limits for combinations of primary and secondary stresses in pressure vessels is based on a rather long history of experience and has proven, for the most part, reliable. However, such an experience base does not exist for reactor fuel plates; thus, experiments are needed to establish these limits.

Tests have been set up to help establish design limit combinations of pressure and thermal loads for reactor fuel plates, and the results are presented in this report. A pressure load corresponding to a specific flow velocity was established using the results reported in Refs. 3 and 5, and the corresponding stresses were calculated. A thermal load developed by heating the plates and cooling the support boundaries was superimposed on the pressure load, and the corresponding stresses were calculated. Data collection from the tests included the pressure load, the boundary temperatures, the plate temperatures, the strain at different points on the plates resulting from the loads, and the permanent strain at different points on the plates resulting from the superimposed loads. After each test the data were examined to see if a plate had sufficient permanent set to alter significantly the channel 


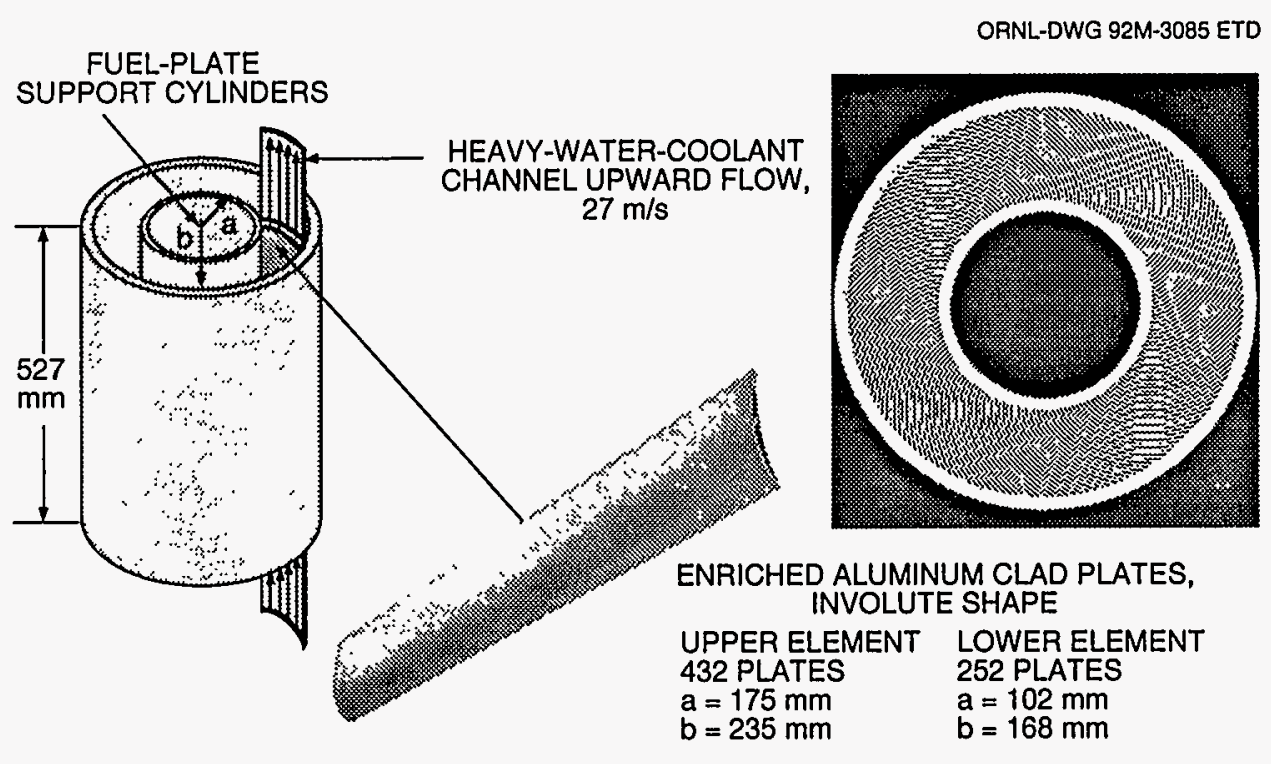

Fig. 1.1. Fuel plate arrangement. 
cross-sectional area between plates. In an operating reactor, the channel cross-sectional area between plates is the coolant flow channel, and if this area were restricted, the plate temperature would rise and could result in plate failure. 


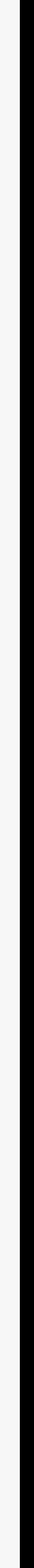




\section{PLATE CALCULATIONS}

When this test was being set up, it appeared that the design of the reactor was going to change from a two-element core operating at a coolant velocity of $25 \mathrm{~m} / \mathrm{s}(82.0 \mathrm{fps})$ to a three-element core operating at a coolant velocity of $20 \mathrm{~m} / \mathrm{s}$ (65.6 fps). In addition, it was estimated that the average plate temperature would be reduced from $218^{\circ} \mathrm{C}$ to $170^{\circ} \mathrm{C}\left(338^{\circ} \mathrm{F}\right)$. The support boundary temperature was estimated to remain the same, $52^{\circ} \mathrm{C}\left(125^{\circ} \mathrm{F}\right)$. With this anticipated change, the involute plate from the outer fuel element of the three-element core was selected for the test. Calculations indicated that this plate would have the highest operating stresses resulting from the combined stresses from pressure and the thermal load. Specifications for this plate include the following:

Inner support radius, $\mathrm{mm}$ (in.)

Outer support radius, $\mathrm{mm}$ (in.)

Involute angle, radians

Arc length, mm (in.)
231 (9.094)

281 (11.063)

0.6926

$55.41(2.181)$

Plate stresses resulting from the coolant flow and from the thermal load for design considerations are calculated as follows.

To estimate the pressure load on the plates from the coolant flow, the formulation based on experiment and reported in Refs. 3 and 5 was used:

$$
\frac{\Delta p}{\rho V^{2}}=0.040\left(\frac{V h}{V}\right)^{0.177} \text {, }
$$

where

$\Delta p=$ average pressure difference across a plate,

$V=$ average coolant velocity,

$h=$ channel thickness,

$\rho=$ coolant density,

$v=$ coolant kinematic viscosity.

Equation (1) relates the average pressure load on a fuel plate to the coolant flow velocity. Equilibrium loads in a plate, which are required to resist the pressure load, induce stresses in the plate. An analytical solution based on energy concepts was developed to evaluate the required equilibrium loads for determining the plate stress values. Referring to the free body diagram of the involute plate shown in Fig. 2.1, the equilibrium loads needed are

$$
\begin{aligned}
M & =M_{o p}+N_{o p} a(\sin \phi-\phi \cos \phi)+V_{o p} a(1-\cos \phi-\phi \sin \phi) \\
& +\Delta p a^{2}\left(1+\frac{\phi^{2}}{2}-\cos \phi-\phi \sin \phi\right) \text { and } \\
N & =V_{o p} \sin \phi+N_{o p} \cos \phi-\Delta p a(\phi-\sin \phi)
\end{aligned}
$$




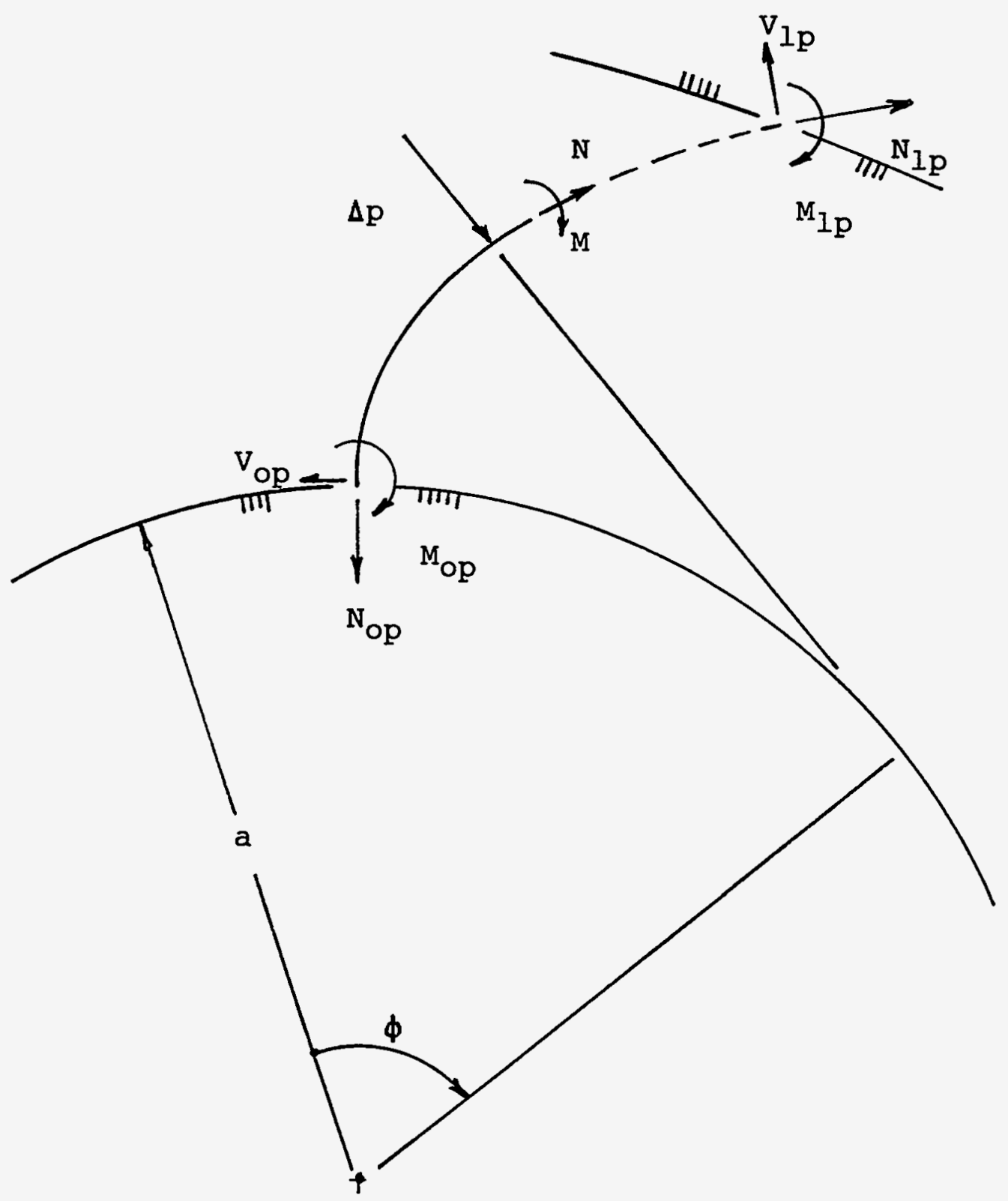

Fig. 2.1. Free body diagram of fuel plate with $\Delta p$ load. 
where

$M=$ moment at any section for a pressure load,

$M_{o p}=$ boundary moment at $\phi=0$ for a pressure load,

$N=$ tangent force at any section for a pressure load,

$N_{o p}=$ boundary tangent force at $\phi=0$ for a pressure load,

$a=$ involute radius and inside support radius of plate,

$V_{o p}=$ boundary shear force at $\phi=0$ for a pressure load,

$\phi=$ involute angle.

The unknown boundary loads at $\phi=0$ were determined by utilizing strain energy $(U)$ and Castigliano's theorems where three equations are developed to solve for the three unknowns. The three equations include

$$
\frac{\partial U}{\partial M_{o p}}=0=\int_{0}^{\phi_{1}} \frac{M}{E I} \frac{\partial M}{\partial M_{o p}} a \phi d \phi,
$$

because the change in slope at the origin is zero as load is applied, then

$$
\frac{\partial U}{\partial N_{o p}}=0=\int_{0}^{\phi_{1}} \frac{M}{E I} \frac{\partial M}{\partial N_{o p}} a \phi d \phi+\int_{0}^{\phi_{1}} \frac{N}{A E} \frac{\partial N}{\partial N_{o p}} a \phi d \phi,
$$

because the deflection at the origin in the tangential direction is zero as load is applied, and

$$
\frac{\partial U}{\partial V_{o p}}=0=\int_{0}^{\phi_{1}} \frac{M}{E I} \frac{\partial M}{\partial V_{o p}} a \phi d \phi+\int_{0}^{\phi_{1}} \frac{N}{A E} \frac{\partial N}{\partial V_{o p}} a \phi d \phi
$$

because the deflection at the origin in the normal direction is zero as load is applied,

where

$\phi_{1}=$ total involute angle,

$E=$ plate material modulus of elasticity,

$A=$ area that supports the tangential and shear loads,

$I=$ moment of inertia for area $A$. 
When Eqs. (3-5) are expanded using Eqs. (2), three equations are realized that can be solved for the three boundary loads at $\phi=0$. The three boundary loads at the outside boundary can be found from equilibrium as

$$
\begin{aligned}
M_{l p} & =M_{o p}+N_{o p} a\left(\sin \phi_{l}-\phi_{l} \cos \phi_{l}\right)-V_{o p} a\left(\cos \phi_{l}+\phi_{l} \sin \phi_{l}-1\right) \\
& +\Delta p a^{2}\left(1+\frac{\phi^{2}}{2}-\cos \phi_{l}-\phi_{l} \sin \phi_{l}\right) \\
N_{l p} & =N_{o p} \cos \phi_{l}+V_{o p} \sin \phi_{l}-\Delta p a\left(\phi_{l}-\sin \phi_{l}\right), \text { and } \\
V_{l p} & =N_{o p} \sin \phi_{l}-V_{o p} \cos \phi_{l}+\Delta p a\left(1-\cos \phi_{l}\right)
\end{aligned}
$$

where

$M_{l p}=$ the boundary moment at the outer boundary support,

$N_{l p}=$ the tangential load at the outer boundary support,

$V_{l p}=$ the shear load at the outer boundary support.

Having the moment load and tangential load at any section of the plate allows the plate stresses to be calculated. There is a singularity at the origin of the involute where the radius of curvature for the involute is zero. Theoretically, this produces an infinite stress because of the curvature effect. However, the region where the curvature is significant is very small (less than $2 \mathrm{~mm}$ ), and a zero curvature cannot realistically be fabricated, suggesting that this effect should be neglected in assessing design limits. Neglecting the effect of curvature, the plate stresses are determined using straight beam theory involving the involute moment load and the tangential load. Finally, it was determined that the maximum plate stresses occur at the intersection with one of the support boundaries. The dimensions of the involute plate will dictate which support boundary intersection has the maximum stress.

For the plates used in this test, the stress calculations show $\sigma_{\mathrm{op}} / \Delta \mathrm{p}=137$, the maximum principal stress magnitude per unit pressure at the inner support, and $\sigma_{\mathrm{lp}} / \Delta \mathrm{p}=264$, the maximum principal stress magnitude per unit pressure at the outer support.

To evaluate the stresses resulting from the thermal load, an average plate temperature and a different average boundary temperature are assumed. The difference in expansion between the side walls and the plates will induce plate stresses in the longitudinal and in the transverse (span) directions. The stresses in the span direction were minimized in the reactor design by letting one of the boundaries float; however, significant thermal stresses in the span direction still exist. The stress magnitudes resulting from the combination of the span thermal stresses with the stresses from the pressure load present potential problem areas that must be considered in an evaluation of the plate design. There is no thermal stress minimization in the longitudinal direction, and the resulting large longitudinal stresses produce potential problem areas that also must be considered in an evaluation of the plate design.

To calculate the thermal stresses in the span direction, an energy solution was used. The boundary conditions were assumed to be such that one support cylinder could rotate relative to the other support cylinder. The radial distance between the support channels essentially remains constant and forces all 
of the deformation to occur in the plates. First the inner support is removed to let the plate expand in the $N_{o r}$ direction (see Fig. 2.2) by

$$
\alpha y_{r} \Delta T
$$

where

$\Delta T=$ average temperature difference between plate and side walls,

$\alpha=$ plate coefficient of thermal expansion,

$y_{r}=$ the $y$-coordinate projection of the plate.

Next, the inner support is replaced, in effect removing the plate expansion that was initially allowed in the $N_{o t}$ (radial) direction and is expressed as

$$
\frac{\partial U}{\partial N_{o t}}=-\alpha y_{r} \Delta T=\int_{0}^{\phi_{t}} \frac{M}{E I} \frac{\partial M}{\partial N_{o t}} a \phi d \phi+\int_{0}^{\phi_{t}} \frac{N}{A E} \frac{\partial N}{\partial N_{o t}} a \phi d \phi,
$$

where

$$
N_{o t}=\text { the plate tangent boundary load at } \phi=0 \text { for thermal loading and }
$$

where $M$ and $N$ have the same format as in Eqs. (2) with $\Delta \mathrm{p}=0$. The plate deflection in the tangential direction is expressed both in terms of rotation $\left(\partial U / \partial M_{o f}\right)$ times the radius $(a)$ and as $\left(\partial U / \partial V_{o t}\right)$ or

$$
-a \int_{0}^{\phi_{l}} \frac{M}{E I} \frac{\partial M}{\partial M_{o t}} a \phi d \phi=\int_{0}^{\phi_{t}} \frac{M}{E I} \frac{\partial M}{\partial V_{o t}} a \phi d \phi+\int_{0}^{\phi_{1}} \frac{N}{A E} \frac{\partial N}{\partial V_{o t}} a \phi d \phi,
$$

where

$M_{o t}=$ the plate boundary moment load at $\phi=0$ for thermal loading,

$V_{\alpha}=$ the plate shear load at $\phi=0$ for thermal loading.

In developing this solution, equilibrium with the inner support cylinder is required:

$$
\left(V_{o t}\right) a+M_{o t}=0
$$

Expanding Eqs. (7 and 8) with the type of equations shown in Eqs. (2) and solving simultaneously with Eq. (9) yields a solution for evaluating $M_{o r}, N_{o r}$ and $V_{o r}$. Equilibrium yields the boundary loads at the outer support cylinder as 


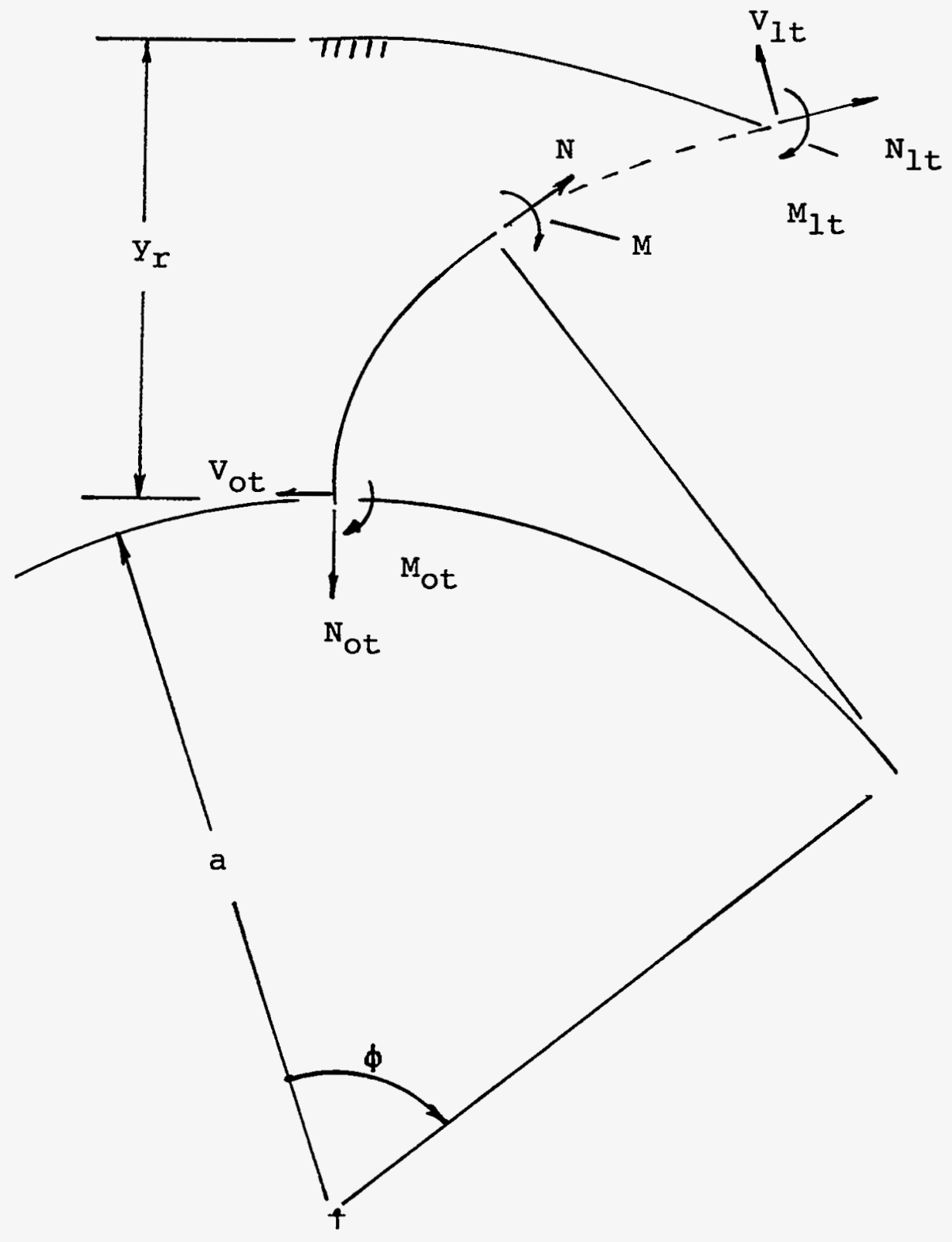

Fig. 2.2. Free body diagram of fuel plate with $\Delta T$ load. 


$$
\begin{aligned}
& M_{l t}=M_{o t}+N_{o t} a\left(\sin \phi_{l}-\phi_{l} \cos \phi_{l}\right)-V_{o t} a\left(\cos \phi_{l}+\phi_{l} \sin \phi_{l}-1\right), \\
& N_{l t}=N_{o t} \cos \phi_{l}+V_{o t} \sin \phi_{l}, \text { and } \\
& V_{l t}=N_{o t} \sin \phi_{l}-V_{o t} \cos \phi_{l},
\end{aligned}
$$

where

$M_{l l}=$ the plate boundary moment at the outer boundary for thermal loading,

$N_{l t}=$ the plate tangent load at the outer boundary for thermal loading,

$V_{t}=$ the plate shear load at the outer boundary for thermal loading.

Neglecting any curvature effects, the largest span thermal stresses occur at the intersection of the plate with the inner support or at the intersection of the plate with the outer support. The most convenient way to determine which location has the highest stress is to compare the results.

Calculations for the span thermal stresses for the test plates show $\sigma_{o l} / \Delta T=0.143 \mathrm{MPa} /{ }^{\circ} \mathrm{C}$ (11.5 $\left.\mathrm{psi} /{ }^{\circ} \mathrm{F}\right)$, the maximum magnitude of the principal stress at the inner boundary per degree temperature difference from a thermal load, and $\sigma_{l} / \Delta T=0.234 \mathrm{MPa} /{ }^{\circ} \mathrm{C}\left(18.9 \mathrm{psi} /{ }^{\circ} \mathrm{F}\right)$, the maximum magnitude of the principal stress at the outer boundary per degree temperature difference from a thermal load.

Calculations for the longitudinal plate stresses are approximated by using the average stresses developed in the longitudinal direction that result from the average temperature difference between the support cylinders and the plate. Referring to the free body shown in Fig. 2.3, equilibrium requires

$$
F_{p l}+F_{o s .}+F_{i s .}=0 \text {, }
$$

where

$F_{p l}=$ the average axial force in the plates,

$F_{o . s .}=$ the average axial force in the outside support,

$F_{L s .}=$ the average axial force in the inside support.

Geometry requires

$$
\delta_{p l}=\delta_{o . s .}=\delta_{i . s .},
$$

where

$\delta_{p l}=$ average axial deformation of the plates,

$\delta_{o . s .}=$ average axial deformation of the outside support,

$\delta_{i s .}=$ average axial deformation of the inside support.

The force-deformation relations for a uniaxial structure are 


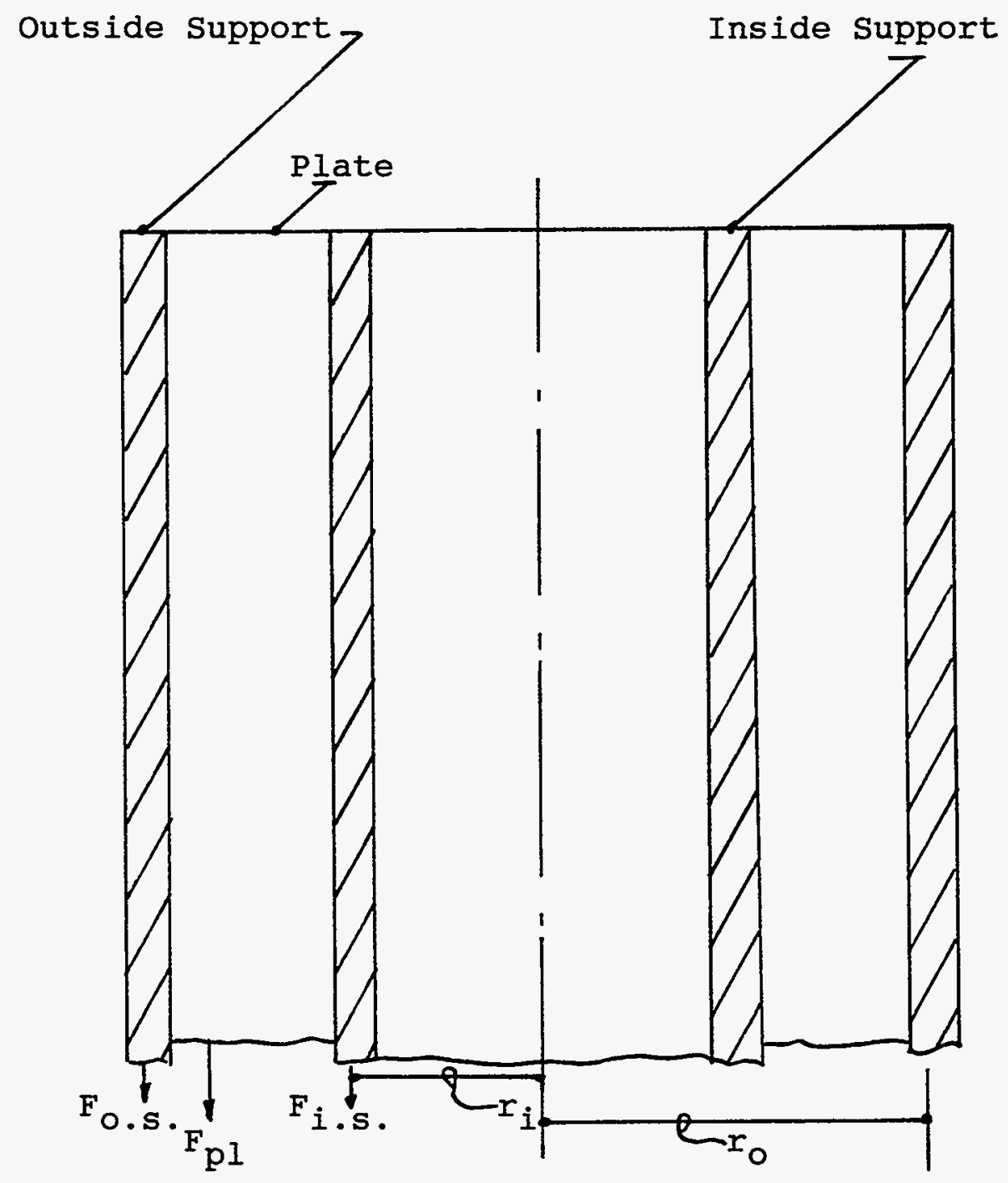

Fig. 2.3. Free body diagram of longitudinal thermal forces. 


$$
\begin{aligned}
& \delta_{p l}=\frac{F_{p l} l_{p l}}{A_{p l} E_{p l}}+\alpha_{p l} l_{p l} T_{p l}, \\
& \delta_{o . s .}=\frac{F_{o . s . o s .}}{A_{o s .} E_{o s .}}+\alpha_{o . s .0 . s .} T_{o s .} \text {, and } \\
& \delta_{i . s .}=\frac{F_{i . s . i s .} l_{\text {. }}}{A_{i . s .} E_{i . s .}}+\alpha_{i . s .} l_{i . s .} T_{i . s .},
\end{aligned}
$$

where

$l=$ length of element,

$A=$ cross-sectional area of element,

$T=$ average temperature of element.

Noting that the plates and support cylinders have the same length, the same modulus of elasticity, and the same coefficient of thermal expansion, Eqs. (11, 12, and 13) are solved to yield

$$
\begin{aligned}
& F_{p l}=-E \alpha A_{p l} \Delta T \frac{\left(A_{o . s .}+A_{i . s .}\right)}{\left(A_{p l}+A_{o . s .}+A_{i . s .}\right)}, \\
& F_{o . s .}=E \alpha A_{o . s .} \Delta T \frac{A_{p l}}{\left(A_{p l}+A_{o s .}+A_{i . s}\right)}, \text { and } \\
& F_{i . s .}=E \alpha A_{i . s .} \Delta T_{\frac{A_{p l}}{\left(A_{p l}+A_{o s .}+A_{i . s .}\right)}}
\end{aligned}
$$

where $\Delta T$ is the average temperature difference between the plates and supports. The average longitudinal principal stress is found by using Eqs. (14) and dividing by the appropriate cross-sectional area. The longitudinal (axial) average principal stress for the test plates is $\sigma_{a x} / \Delta T=-0.575 \mathrm{MPa} /{ }^{\circ} \mathrm{C}$ $\left(46.3 \mathrm{psi} /{ }^{\circ} \mathrm{F}\right)$

To get an appreciation for the significance of these stress calculations, assume the planned operating conditions of the three-element core:

$V=20 \mathrm{~m} / \mathrm{s}(65.6 \mathrm{fps})$

$\Delta T=170-52=118^{\circ} \mathrm{C}\left(212.4^{\circ} \mathrm{F}\right)$.

Using these conditions, the following results were calculated:

$\Delta p=0.0960 \mathrm{MPa}(13.9 \mathrm{psi})$, the plate pressure load,

$\sigma_{o p}=13.1 \mathrm{MPa}(1910 \mathrm{psi})$, that part of the span principal stress that develops at the inner boundary because of the pressure load, 
$\sigma_{l p}=25.4 \mathrm{MPa}$ (3680 psi), that part of the span principal stress that develops at the outer boundary because of the pressure load,

$\sigma_{o t}=16.9 \mathrm{MPa}(2450 \mathrm{psi})$, that part of the span principal stress that develops at the inner boundary because of the thermal load,

$\sigma_{l t}=27.6 \mathrm{MPa}$ (4010 psi), that part of the span principal stress that develops at the outer boundary because of the thermal load,

$\sigma_{a x}=-67.8 \mathrm{MPa}(-9840 \mathrm{psi})$, the principal stress that develops in the longitudinal direction from the thermal load.

To facilitate further discussion, the stresses occurring because of the pressure load are designated primary stresses and the stresses occurring because of the thermal load are designated secondary stresses, which are similar to the designations used in the ASME pressure vessel code. ${ }^{6}$ If the pressure load is on the concave side of the plate, the critical primary stress is tensile. If the pressure load is on the convex side of the plate, the critical primary stress is compressive. The most critical primary stress location is at the intersection of the plate with the outer support cylinder on the concave side of the plate. The most critical secondary stress occurs at the intersection of the plate with the outside support cylinder, as in the case of the most critical primary stress. However, the most critical secondary stress occurs on the convex side of the plate and is always compressive because the plates are always at a higher temperature than the support boundaries.

Further examination of the calculated results shows that, if the primary and the secondary stress at design operating conditions are superimposed at the most critical location, the magnitude is $52.3 \mathrm{MPa}$ (7590 psi). The yield stress for this material is $55 \mathrm{MPa}$ (7980 psi). At the design operating conditions, calculations show that the maximum principal stress in the span direction is slightly below yield and indicate that the plate will not fail under these conditions. However, the rationale of giving the same design weight to the primary stress (pressure stress) and to the secondary stress (thermal stress) is lacking experimental support; hence, the need or purpose for the tests herein reported. Further, it should be noted that the secondary stress in the longitudinal direction calculates to be $-67.8 \mathrm{MPa}$ ( -9840 psi). The magnitude of this stress is above the yield point, and it is important to determine experimentally the response of the plate to this secondary stress. 


\section{DESIGN AND EVALUATION OF THE EXPERIMENTAL SETUP}

A cross-sectional view of the test section is shown in Fig. 3.1. Each of the two involute plates was made by pressing a flat aluminum $6061-\mathrm{O}$ plate, which had a thickness of $1.27 \mathrm{~mm}(0.050 \mathrm{in}$.), between two stainless steel mandrels that had been machined to the specified involute dimensions (Fig. 3.2). Each plate was heated to $385^{\circ} \mathrm{C}\left(725^{\circ} \mathrm{F}\right)$ while pressed between the mandrels, held for two hours at this temperature, and then slowly allowed to cool to room temperature for removing residual stresses that developed during the forming of the plates. On removal from the mandrels, the test plates conformed without any detectable variation to the mandrel pattern. When assembled, the test section was heated in a digitally controlled convection oven while the support boundaries were cooled by flowing water through the support boundaries. The support boundaries were overlaid with insulation to get a temperature difference between the heated plates and the cooled boundaries more efficiently. The temperature of each plate was monitored with a sensor. The inlet cooling water temperature and outlet cooling water temperature were also monitored with sensors. The boundary temperatures were controlled by adjusting the coolant flow rate through the boundaries with needle valves.

The inside support boundary was designed to float, that is, to rotate about the design centerline of the support cylinder; but the plate boundary was constrained from a radial displacement. This test design feature was intended to simulate the floating support cylinder (boundary) of the ANS fuel element. The "flow channel" between the plates had three small tubes inserted at the top to apply pressure between the plates for simulating the flow load. All openings and boundaries were sealed with a silicone rubber sealant to prevent leakage of the coolant and the pressurizing air. Sealing the entrance and exit of the fuel plate coolant channel was a compromise in that the operating reactor would have open channels, but simulating the reactor flow load with a static load required sealing the entrance and exit to contain the pressure. The effect of this compromise was to have a plate closer to a plane strain condition in the longitudinal direction rather than to a free end condition.

The test section before the support boundary insulation was applied is shown in Fig. 3.3. In this picture some of the test sensors can be seen. Twelve strain gauges (six on each plate) were mounted on the plates to monitor the plate strain and to help determine yielding of the plates from the tests. Data from the strain gauges will allow for calculation of the primary and secondary stresses at the selected test points. The locations of the gauges are shown on Fig. 3.4. One pair of gauges is located near each support boundary where maximum stresses occur, and the other pair is located at the point that had maximum deflection when the plates were loaded with pressure. For later data reference, gauges located on the convex side of a plate have a suffix 0 , while gauges located on the concave side of a plate have a suffix $i$. The longitudinal location of each pair of gauges was varied so that if there was significant variation in the stress field near the central length of the plate, the gauge readings would signal that effect. The gauges were mounted in pairs so the strain in the span direction and that in the longitudinal direction at a point could be determined. Knowing the strain in two principal directions allowed the principal stresses to be calculated. Thus, the stress at three points on each plate could be monitored for the relation of the primary and secondary stress to yield. A temperature sensor was mounted at the midpoint of each plate to assess the temperature of each plate during the tests. The assembled test section is shown in Fig. 3.5. In this figure the manifold for regulating the coolant flow to the boundaries and the digitally controlled oven can be seen. Note also the pressure regulator on top of the oven for controlling the pressure load and the strain- and temperature-reading system.

After everything was assembled, an evaluation of the experimental setup was made. It was determined that the maximum difference in temperature achievable between the plates and support boundaries was on the order of $24^{\circ} \mathrm{C}\left(43^{\circ}\right)$, which corresponded to a plate temperature of $54^{\circ} \mathrm{C}$ $\left(129^{\circ} \mathrm{F}\right)$ and $a 30^{\circ} \mathrm{C}\left(86^{\circ} \mathrm{F}\right)$ boundary. Such a large thermal resistance as represented by a convection oven temperature of $260^{\circ} \mathrm{C}\left(500^{\circ} \mathrm{F}\right)$ and a plate temperature of $54^{\circ} \mathrm{C}\left(129^{\circ} \mathrm{F}\right)$ was not anticipated, and 


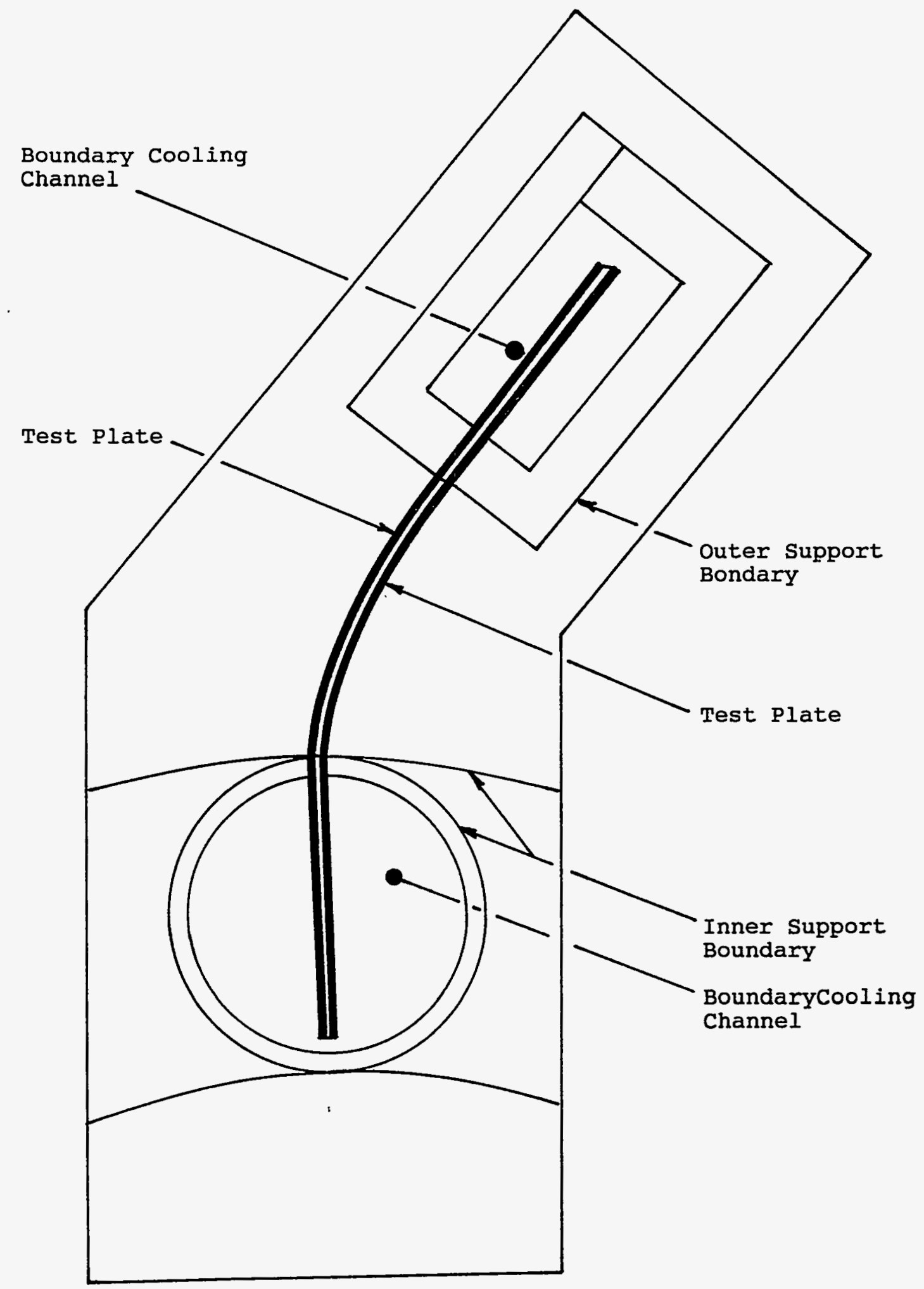

Fig. 3.1. Cross section of the test section. 


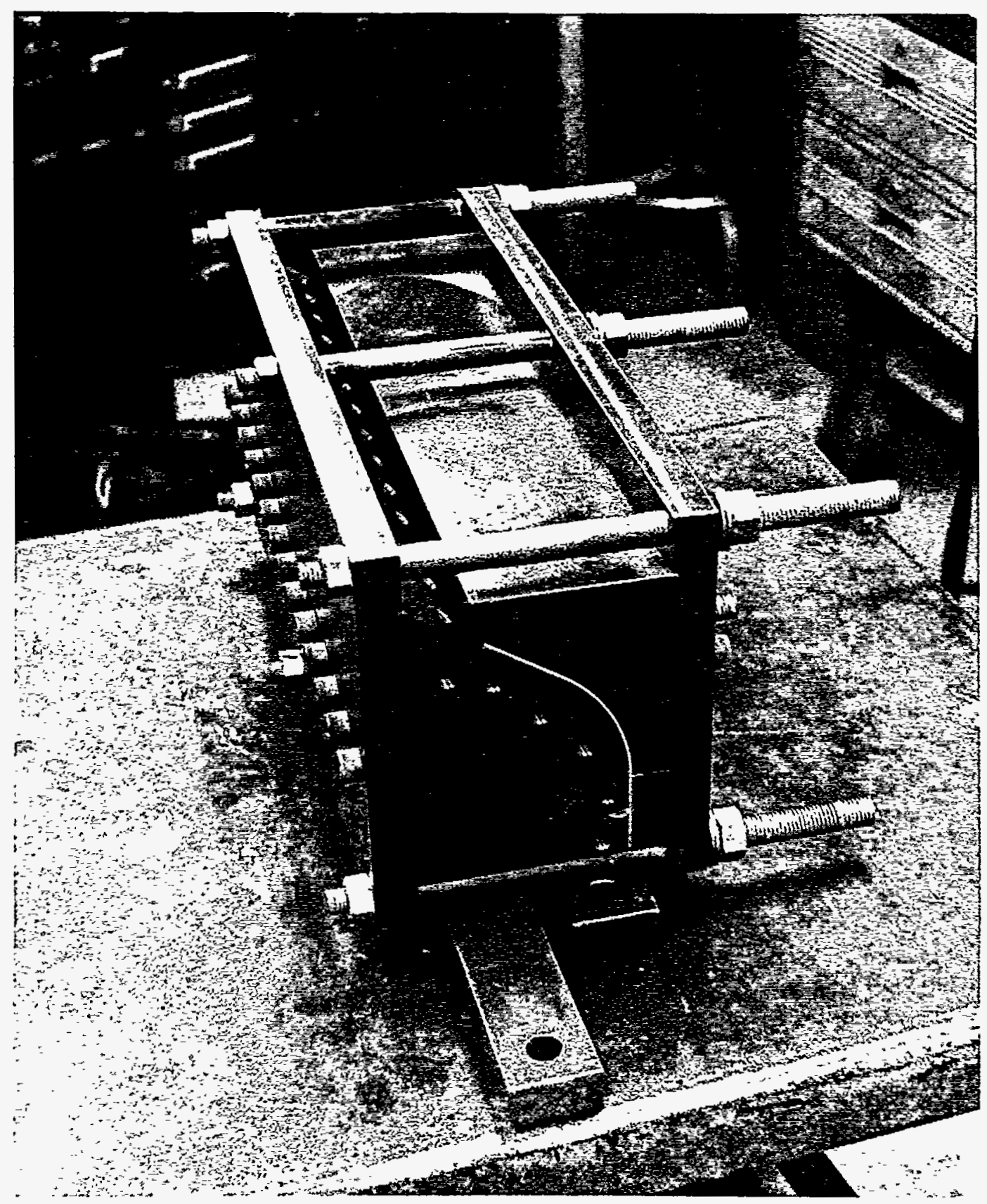

Fig. 3.2. Forming involute plates. 


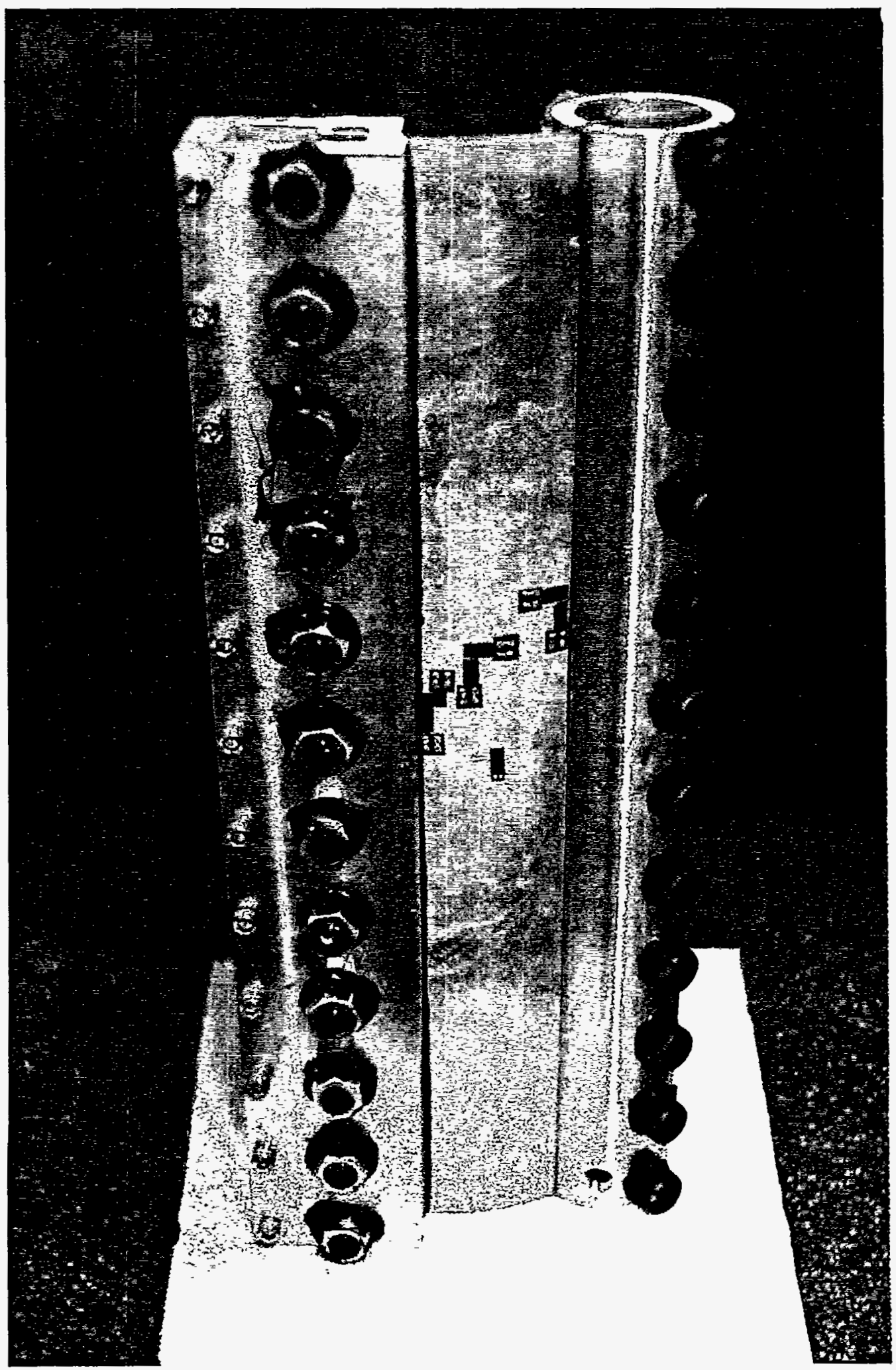

Fig. 3.3. Test section. 

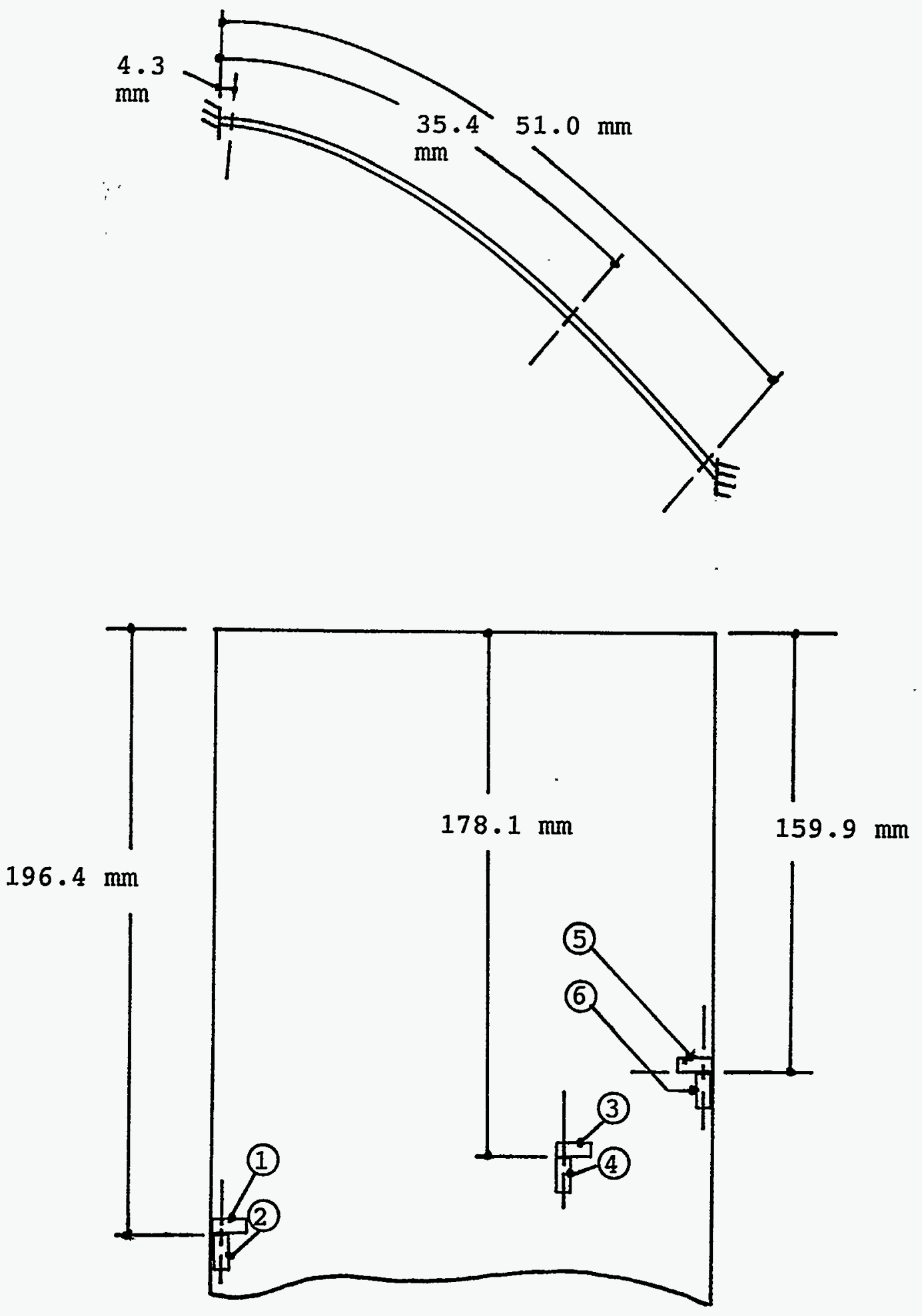

Fig. 3.4. Strain gauge locations. 


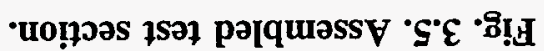

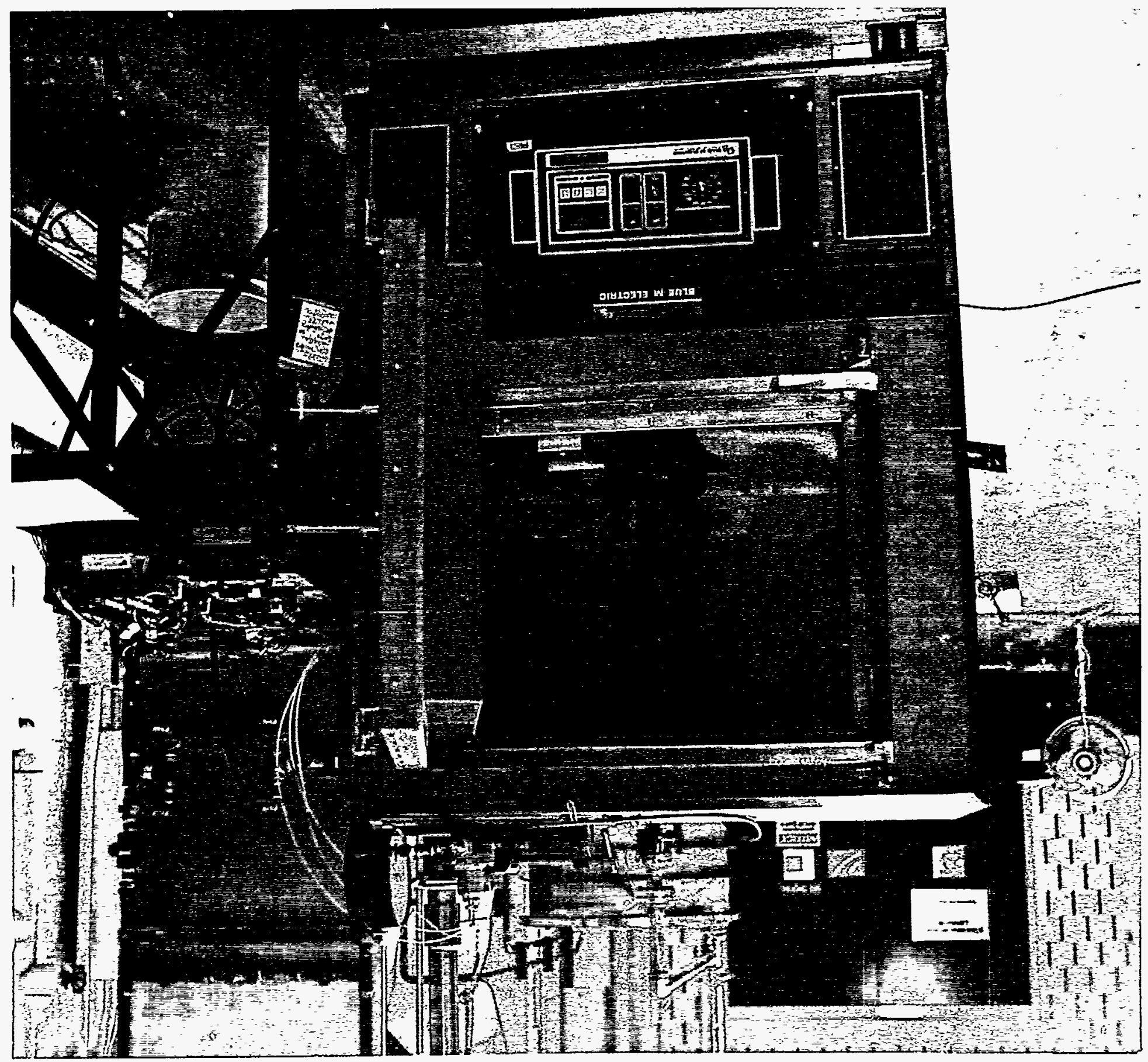




\section{3-7}

the result lowered the magnitude of the secondary (thermal) stress that could be realized in the test. However, it was also determined that the "floating boundary support" did not function as designed. The strains that were found at the test points were closer in magnitude to a fixed-boundary condition than to a floating-boundary condition, indicating that the floating boundary was not functioning as designed. The result of this design variation increased the magnitude of the secondary stress and offset the effect of the lower than expected temperature difference between the plates and boundaries. 



\section{TEST DATA}

The correspondence of the data taken to a specific plate sensor is given in Table 4.1. Each test consisted of taking data first with a pressure load only, next with the thermal load only, and last with the pressure and thermal loads combined. The same thermal load was used in each test while the pressure load was increased with each test. Temperature compensation was accomplished by having the compensating gauge mounted on a $6061-\mathrm{O}$ aluminum piece that was unrestrained and located in the oven. The aluminum piece also had a temperature sensor mounted on it. The compensator wires and the active strain gauge wires were all of the same length and had the same environment for compensation purposes. However, the strain gauges on the plates, which were cooled through conduction to the boundaries, were not at the same temperature as the compensating gauge and required correction of the strain readings using the manufacturer's temperature curve for the active and compensating gauges supplied with each gauge lot. In addition, reading strain information and temperature information from the same strain indicator made it more convenient to set the strain indicator with a gauge factor of 2.000 for all readings and then adjust the strain gauge readings later for the actual 2.090 gauge factor. Tables $4.2-4.7$ list the recorded data. 
Table 4.1. Data identification with instrument readout

\begin{tabular}{|c|c|}
\hline Channel & Sensor ${ }^{n}$ \\
\hline \multicolumn{2}{|r|}{ Balance box I } \\
\hline 1 & 10 \\
\hline 2 & 20 \\
\hline 3 & 30 \\
\hline 4 & 40 \\
\hline 5 & 50 \\
\hline 6 & 60 \\
\hline 7 & $1 \mathrm{i}$ \\
\hline 8 & $2 \mathrm{i}$ \\
\hline 9 & $3 i$ \\
\hline 10 & $4 \mathrm{i}$ \\
\hline \multicolumn{2}{|r|}{ Balance box $\mathbf{I}$} \\
\hline 1 & $5 i$ \\
\hline 2 & $6 i$ \\
\hline 3 & Cooling water inlet temperature $\left({ }^{\circ} \mathrm{F}\right)$ times 10 \\
\hline 4 & $\begin{array}{l}\text { Cooling water outlet temperature }\left({ }^{\circ} \mathrm{F}\right) \text { from inner } \\
\text { boundary times } 10\end{array}$ \\
\hline 5 & $\begin{array}{l}\text { Cooling water outlet temperature }\left({ }^{\circ} \mathrm{F}\right) \text { from outer } \\
\text { boundary times } 10\end{array}$ \\
\hline 6 & $\begin{array}{l}\text { Temperature }\left({ }^{\circ} \mathrm{F}\right) \text { times } 10 \text { of the test plate with the } \\
\text { concave surface being exterior }\end{array}$ \\
\hline 7 & $\begin{array}{l}\text { Temperature }\left({ }^{\circ} \mathrm{F}\right) \text { times } 10 \text { of the test plate with the } \\
\text { convex surface being exterior }\end{array}$ \\
\hline 8 & Compensator gauge temperature $\left({ }^{\circ} \mathrm{F}\right)$ times 10 \\
\hline
\end{tabular}

"Sensor suffix $O$ designates gauges that were mounted on test plate with the convex surface being exterior. Sensor suffix $i$ designates gauges that were mounted on test plate with the concave surface being exterior. 
Table 4.2. Strain gauge readings from test at $68.9 \mathrm{kPa}(10 \mathrm{psi})^{a}$

\begin{tabular}{|c|c|c|c|c|c|c|}
\hline Channel & $\begin{array}{l}\text { Initial, } \\
\text { no load }\end{array}$ & $\begin{array}{c}\text { Pressure } \\
\text { only }\end{array}$ & $\begin{array}{c}\text { Initial } \\
(8: 30 \text { a.m. })\end{array}$ & $\begin{array}{c}\text { Temperature }^{b} \\
\text { only } \\
\text { (9:15 a.m.) }\end{array}$ & $\begin{array}{c}\text { Temperature } \\
\text { plus pressure } \\
(9: 23 \text { a.m.) }\end{array}$ & $\begin{array}{c}\text { Final, } \\
\text { no load } \\
\text { (1:20 p.m.) }\end{array}$ \\
\hline \multicolumn{7}{|c|}{$\operatorname{Box} 1$} \\
\hline 1 & -1 & -99 & 2 & -200 & -305 & -5 \\
\hline 2 & 1 & -6 & 2 & -332 & -325 & 18 \\
\hline 3 & 4 & 186 & 1 & -40 & 137 & 22 \\
\hline 4 & 2 & -10 & 1 & -473 & -472 & 21 \\
\hline 5 & 2 & -123 & 0 & -276 & -402 & 7 \\
\hline 6 & 2 & 2 & 1 & -298 & -286 & 19 \\
\hline 7 & 4 & -143 & 1 & -141 & -275 & 27 \\
\hline 8 & 3 & 35 & 4 & -179 & -146 & 21 \\
\hline 9 & 3 & 155 & -2 & -120 & 43 & 18 \\
\hline 10 & 3 & 0 & -2 & -268 & -270 & 18 \\
\hline \multicolumn{7}{|c|}{ Box 2} \\
\hline 1 & -1 & -172 & -1 & -80 & -240 & -13 \\
\hline 2 & 1 & 6 & -4 & -218 & -212 & -9 \\
\hline 3 & 808 & 809 & 785 & 803 & 808 & 818 \\
\hline 4 & 808 & 809 & 784 & 870 & 875 & 815 \\
\hline 5 & 808 & 809 & 786 & 884 & 890 & 814 \\
\hline 6 & 811 & 811 & 786 & 1120 & 1100 & 844 \\
\hline 7 & 812 & 812 & 788 & 1267 & 1275 & 845 \\
\hline 8 & 803 & 802 & 780 & 4916 & 4930 & 819 \\
\hline
\end{tabular}

${ }^{a}$ Readings from strain gauges are in microstrain. Readings from temperature sensors (box 2, channels 3-8) are 'F times 10. Instrumentation set up with a gauge factor of 2.000 .

${ }^{b}$ Set temperature $=500^{\circ} \mathrm{F}$; oven temperature $=500^{\circ} \mathrm{F}$. 
Table 4.3. Strain gauge readings from test at $137.9 \mathrm{kPa}(20 \mathrm{psi})^{a}$

\begin{tabular}{|c|c|c|c|c|c|c|}
\hline Channel & $\begin{array}{l}\text { Initial, } \\
\text { no load }\end{array}$ & $\begin{array}{c}\text { Pressure } \\
\text { only }\end{array}$ & $\begin{array}{c}\text { Initial } \\
\text { (8:30 a.m.) }\end{array}$ & $\begin{array}{c}\text { Temperature }^{b} \\
\text { only } \\
(9: 15 \text { a.m. })\end{array}$ & $\begin{array}{c}\text { Temperature } \\
\text { plus pressure } \\
(9: 25 \text { a.m.) }\end{array}$ & $\begin{array}{c}\text { Final, } \\
\text { no load } \\
\text { (1:30 p.m.) }\end{array}$ \\
\hline \multicolumn{7}{|c|}{ Box 1} \\
\hline 1 & -1 & -211 & 2 & -195 & -503 & -54 \\
\hline 2 & 1 & -15 & 1 & -313 & -305 & 22 \\
\hline 3 & 4 & 355 & 6 & -38 & 426 & 128 \\
\hline 4 & 2 & -21 & 4 & -465 & -468 & 20 \\
\hline 5 & 2 & -250 & -1 & -274 & -594 & -30 \\
\hline 6 & 2 & 1 & 5 & -286 & -268 & 22 \\
\hline 7 & 4 & -272 & 4 & -139 & -385 & 50 \\
\hline 8 & 3 & 62 & -2 & -185 & -115 & 21 \\
\hline 9 & 3 & 316 & 1 & -118 & 291 & 52 \\
\hline 10 & 3 & -8 & 1 & -268 & -268 & 21 \\
\hline \multicolumn{7}{|c|}{ Box 2} \\
\hline 1 & -1 & -308 & -2 & -78 & -367 & 40 \\
\hline 2 & 1 & 8 & 0 & -213 & -211 & -13 \\
\hline 3 & 808 & 809 & 804 & 812 & 814 & 824 \\
\hline 4 & 808 & 809 & 804 & 876 & 881 & 825 \\
\hline 5 & 808 & 809 & 805 & 894 & 898 & 898 \\
\hline 6 & 811 & 811 & 804 & 1124 & 1084 & 846 \\
\hline 7 & 812 & 812 & 806 & 1273 & 1285 & 847 \\
\hline 8 & 803 & 802 & 796 & 4914 & 4922 & 834 \\
\hline
\end{tabular}

${ }^{a}$ Readings from strain gauges are in microstrain. Readings from temperature sensors (box 2, channels 3-8) are ${ }^{\circ} \mathrm{F}$ times 10 . Instrumentation set up with a gauge factor of 2.000 .

${ }^{b} \mathrm{Set}$ temperature $=500^{\circ} \mathrm{F}$; oven temperature $=500^{\circ} \mathrm{F}$. 
Table 4.4. Strain gauge readings from test at $172.4 \mathrm{kPa}(25 \mathrm{psi})^{a}$

\begin{tabular}{|c|c|c|c|c|c|c|}
\hline Channel & $\begin{array}{l}\text { Initial, } \\
\text { no load }\end{array}$ & $\begin{array}{c}\text { Pressure } \\
\text { only }\end{array}$ & $\begin{array}{c}\text { Initial } \\
\text { (9:06 a.m.) }\end{array}$ & $\begin{array}{c}\text { Temperature }^{b} \\
\text { only } \\
\text { (9:51 a.m.) }\end{array}$ & $\begin{array}{l}\text { Temperature } \\
\text { plus pressure } \\
\text { (10:00 a.m.) }\end{array}$ & $\begin{array}{c}\text { Final, } \\
\text { no load } \\
\text { (2:00 p.m.) }\end{array}$ \\
\hline \multicolumn{7}{|c|}{ Box 1} \\
\hline 1 & -1 & -261 & 2 & -180 & -505 & -6 \\
\hline 2 & 1 & -18 & -1 & -302 & -307 & 11 \\
\hline 3 & 4 & 448 & 2 & -54 & 420 & 38 \\
\hline 4 & 2 & -26 & 0 & -450 & -462 & 14 \\
\hline 5 & 2 & -312 & 1 & -280 & -652 & -44 \\
\hline 6 & 2 & 2 & 0 & -281 & -268 & 11 \\
\hline 7 & 4 & -344 & 3 & -153 & -438 & 0 \\
\hline 8 & 3 & 80 & 4 & -185 & -160 & 16 \\
\hline 9 & 3 & 394 & 2 & -113 & 370 & 41 \\
\hline 10 & 3 & -8 & 4 & -264 & -330 & 28 \\
\hline \multicolumn{7}{|c|}{ Box 2} \\
\hline 1 & -1 & -394 & -1 & -68 & -410 & 40 \\
\hline 2 & 1 & 9 & 0 & -212 & -216 & -7 \\
\hline 3 & 808 & 809 & 810 & 819 & 822 & 825 \\
\hline 4 & 808 & 809 & 811 & 885 & 892 & 826 \\
\hline 5 & 808 & 809 & 811 & 900 & 905 & 827 \\
\hline 6 & 811 & 811 & 811 & 1132 & 1182 & 851 \\
\hline 7 & 812 & 812 & 812 & 1283 & 1298 & 852 \\
\hline 8 & 803 & 802 & 802 & 4909 & 4913 & 837 \\
\hline
\end{tabular}

${ }^{a}$ Readings from strain gauges are in microstrain. Readings from temperature sensors (box 2, channels $3-8$ ) are oF times 10. Instrumentation set up with a gauge factor of 2.000 .

${ }^{b}$ Set temperature $=500^{\circ} \mathrm{F}$; oven temperature $=500^{\circ} \mathrm{F}$. 
Table 4.5. Strain gauge readings from test at $206.8 \mathrm{kPa}(30 \mathrm{psi})^{a}$

\begin{tabular}{|c|c|c|c|c|c|c|}
\hline Channel & $\begin{array}{l}\text { Initial, } \\
\text { no load }\end{array}$ & $\begin{array}{c}\text { Pressure } \\
\text { only }\end{array}$ & $\begin{array}{c}\text { Initial } \\
\text { (8:50 a.m.) }\end{array}$ & $\begin{array}{c}\text { Temperature }^{b} \\
\text { only } \\
\text { (9:35 a.m.) }\end{array}$ & $\begin{array}{c}\text { Temperature } \\
\text { plus pressure } \\
(9: 45 \text { a.m.) }\end{array}$ & $\begin{array}{c}\begin{array}{c}\text { Final, } \\
\text { no load }\end{array} \\
(2: 00 \text { p.m. })\end{array}$ \\
\hline \multicolumn{7}{|c|}{ Box 1} \\
\hline 1 & 0 & -350 & 0 & -195 & -520 & -38 \\
\hline 2 & 2 & -28 & -1 & -296 & -295 & 11 \\
\hline 3 & 3 & 512 & 2 & -60 & 466 & 37 \\
\hline 4 & 4 & -37 & 0 & -446 & -450 & 16 \\
\hline 5 & 3 & -355 & 3 & -267 & -661 & -25 \\
\hline 6 & 0 & -9 & 0 & -276 & -257 & 12 \\
\hline 7 & 0 & -373 & -1 & -145 & -440 & 10 \\
\hline 8 & -5 & 80 & -3 & -168 & -160 & 11 \\
\hline 9 & 1 & 514 & 1 & -118 & 380 & -19 \\
\hline 10 & -2 & -22 & -1 & -268 & -351 & 2 \\
\hline \multicolumn{7}{|c|}{ Box 2} \\
\hline 1 & 0 & -344 & 2 & -79 & -504 & -11 \\
\hline 2 & 0 & 8 & 0 & -210 & -208 & -3 \\
\hline 3 & 819 & 819 & 819 & 824 & 827 & 837 \\
\hline 4 & 821 & 821 & 820 & 890 & 899 & 838 \\
\hline 5 & 821 & 821 & 820 & 903 & 910 & 839 \\
\hline 6 & 821 & 821 & 821 & 1120 & 1126 & 858 \\
\hline 7 & 823 & 822 & 822 & 1290 & 1305 & 859 \\
\hline 8 & 813 & 813 & 813 & 4911 & 4918 & 848 \\
\hline
\end{tabular}

${ }^{a}$ Readings from strain gauges are in microstrain. Readings from temperature sensors (box 2, channels 3-8) are ${ }^{\circ} \mathrm{F}$ times 10 . Instrumentation set up with a gauge factor of 2.000 .

${ }^{b}$ Set temperature $=500^{\circ} \mathrm{F}$; oven temperature $=500^{\circ} \mathrm{F}$. 
Table 4.6. Strain gauge readings from test at $275.8 \mathrm{kPa}(40 \mathrm{psi})^{a}$

\begin{tabular}{|c|c|c|c|c|c|c|}
\hline Channel & $\begin{array}{l}\text { Initial, } \\
\text { no load }\end{array}$ & $\begin{array}{c}\text { Pressure } \\
\text { only }\end{array}$ & $\begin{array}{c}\text { Initial } \\
\text { (8:35 a.m.) }\end{array}$ & $\begin{array}{c}\text { Temperature }^{b} \\
\text { only } \\
(9: 25 \text { a.m.) }\end{array}$ & $\begin{array}{c}\text { Temperature } \\
\text { plus pressure } \\
\text { (9:35 a.m.) }\end{array}$ & $\begin{array}{c}\text { Final, } \\
\text { no load } \\
(1: 30 \text { p.m. })\end{array}$ \\
\hline \multicolumn{7}{|c|}{ Box 1} \\
\hline 1 & 3 & -389 & 3 & -200 & -599 & -75 \\
\hline 2 & 3 & -2 & 2 & -285 & -283 & 21 \\
\hline 3 & 3 & 528 & -1 & -68 & 625 & 133 \\
\hline 4 & 3 & -10 & 3 & -439 & -442 & 26 \\
\hline 5 & 1 & -381 & 3 & -275 & -702 & -23 \\
\hline 6 & 1 & 15 & 1 & -275 & -243 & 22 \\
\hline 7 & 2 & -383 & -3 & -158 & -466 & 9 \\
\hline 8 & 0 & 84 & 1 & -173 & -166 & 15 \\
\hline 9 & -1 & 539 & 1 & -122 & 513 & 3 \\
\hline 10 & 2 & -18 & 3 & -260 & -358 & 9 \\
\hline \multicolumn{7}{|c|}{ Box 2} \\
\hline 1 & 0 & -469 & 4 & -85 & -638 & -43 \\
\hline 2 & -1 & 9 & -2 & -218 & -220 & -10 \\
\hline 3 & 810 & 810 & 810 & 819 & 822 & 842 \\
\hline 4 & 810 & 811 & 811 & 882 & 892 & 843 \\
\hline 5 & 811 & 811 & 812 & 909 & 917 & 845 \\
\hline 6 & 810 & 811 & 811 & 1120 & 1127 & 869 \\
\hline 7 & 811 & 811 & 811 & 1285 & 1300 & 870 \\
\hline 8 & 803 & 803 & 804 & 4908 & 4918 & 857 \\
\hline
\end{tabular}

${ }^{a}$ Readings from strain gauges are in microstrain. Readings from temperature sensors (box 2, channels 3-8) are of times 10. Instrumentation set up with a gauge factor of 2.000 .

${ }^{b}$ Set temperature $=500^{\circ} \mathrm{F}$; oven temperature $=500^{\circ} \mathrm{F}$. 
Table 4.7. Strain gauge readings from test at $344.7 \mathrm{kPa}(50 \mathrm{psi})^{a}$

\begin{tabular}{|c|c|c|c|c|c|c|}
\hline Channel & $\begin{array}{l}\text { Initial, } \\
\text { no load }\end{array}$ & $\begin{array}{c}\text { Pressure } \\
\text { only }\end{array}$ & $\begin{array}{c}\text { Initial } \\
\text { (8:45 a.m.) }\end{array}$ & $\begin{array}{c}\text { Temperature }^{b} \\
\text { only } \\
(9: 30 \text { a.m.) }\end{array}$ & $\begin{array}{c}\text { Temperature }^{c} \\
\text { plus pressure } \\
(9: 40 \text { a.m.) }\end{array}$ & $\begin{array}{c}\text { Final, } \\
\text { no load } \\
(1: 30 \text { p.m. })\end{array}$ \\
\hline \multicolumn{7}{|c|}{ Box 1} \\
\hline 1 & 1 & -532 & 0 & -226 & -295 & -135 \\
\hline 2 & 1 & -2 & 1 & -286 & -238 & 67 \\
\hline 3 & 3 & 598 & 1 & -68 & 1358 & 1384 \\
\hline 4 & 1 & -5 & -1 & -435 & -459 & 6 \\
\hline 5 & 2 & -418 & 1 & -276 & -205 & 20 \\
\hline 6 & 1 & 22 & 0 & -270 & -245 & 40 \\
\hline 7 & 3 & -406 & -1 & -117 & -7363 & -7151 \\
\hline 8 & 0 & 84 & 4 & -165 & 314 & 437 \\
\hline 9 & 1 & 756 & -1 & -102 & 8037 & 7854 \\
\hline 10 & 2 & -30 & 2 & -262 & -338 & -52 \\
\hline \multicolumn{7}{|c|}{ Box 2} \\
\hline 1 & -1 & -553 & 1 & -95 & -5517 & -5335 \\
\hline 2 & 1 & 13 & 2 & -205 & -36 & 132 \\
\hline 3 & 826 & 826 & 827 & 824 & 826 & 845 \\
\hline 4 & 826 & 826 & 827 & 888 & 891 & 844 \\
\hline 5 & 826 & 827 & 830 & 913 & 919 & 848 \\
\hline 6 & 826 & 827 & 827 & 1120 & 1130 & 869 \\
\hline 7 & 827 & 828 & 828 & 1298 & 1306 & 873 \\
\hline 8 & 818 & 819 & 821 & 4913 & 4916 & 857 \\
\hline
\end{tabular}

${ }^{\sigma}$ Readings from strain gauges are in microstrain. Readings from temperature sensors (box 2, channels 3-8) are ${ }^{\circ} \mathrm{F}$ times 10 . Instrumentation set up with a gauge factor of 2.000 .

${ }^{b}$ Set temperature $=500^{\circ} \mathrm{F}$; oven temperature $=500^{\circ} \mathrm{F}$.

When the pressure load was applied on top of the thermal load, at about $310.3 \mathrm{KPa}$ (45 psi) an abrupt jump occurred in gauge 10, which was being monitored while the pressure was being applied. The jump was attributed to a plate failure, which was obvious when the oven cooled and the plate was inspected. Thus, the data recorded with pressure and temperature loads were combined and have no significance for use in calculations. 


\section{INTERPRETATION OF THE RESULTS}

The objective of these tests was to examine the possibility of assigning different design weights to primary and secondary stresses, the rationale being that loads producing secondary stresses will relax as material begins to yield and will result in a lower final stress state than if no yielding had occurred. Strain values after temperature compensation and adjustment for the gauge factor are shown together with calculated stress values in Tables 5.1-5.6.

To examine this weighted potential, the stress in the span direction as determined by the strain from the gauges (gauges 50 and 60 ) on the convex side of one of the test plates and near the outside support boundary are shown for each test in Fig. 5.1. This test point had the largest stress magnitude of all the test points. The stresses from pressure load only, from temperature load only, and from combined pressure and temperature loads are shown. It should be noted that when a pressure of $344.7 \mathrm{KPa}(50 \mathrm{psi})$ was applied between the test plates with the thermal load already in place, the plates failed. The plates held the pressure load, but each plate had a large bulge outward from the channel between the plates and extending the length of the plate. Had this deformation occurred in the assembled reactor core, some fuel plates would have made contact and plate burn out would be expected. Examining Fig. 5.1, it can be seen that adding the stress produced only by the pressure load to the stress produced only by the thermal load yields essentially the same stress value as realized when the loads are combined and the stresses evaluated. The secondary stress load is not relaxing as the combined stress level approaches yield. Also it is noted that when the pressure load of $344.7 \mathrm{MPa}$ was applied between the plates that had no thermal load, no failure was evident. However, when this pressure load was applied to the plates that already had a thermal load, plate failure occurred. Thus, the thermal load does not relax sufficiently (if at all) during material yield to prevent failure. As a side note, it can be observed that the plates failed when the test point that had the largest stress magnitude was at approximately $65 \mathrm{MPa}(9428 \mathrm{psi})$, which is above the material yield stress of $55 \mathrm{MPa}$ (7980 psi). It should be recalled that $6061-\mathrm{O}$ aluminum does not have a well-defined yield stress point, but instead the yield stress is based on a strain offset that is somewhat arbitrarily assigned. Further, yield stress is usually based on tensile stress data, and the value would not necessarily be the same if the material were in compression instead of tension.

The next stress point considered is represented by gauges $5 \mathrm{i}$ and $6 \mathrm{i}$. This point is located with the same span plate coordinates as gauges 50 and 60 , but gauges $5 \mathrm{i}$ and $6 \mathrm{i}$ are mounted on the other test plate and on the concave side or exposed side of the plate. There is another difference in the test points on each plate. The pressure load is on the concave side of the plate, on which gauges 50 and 60 are mounted, while the pressure load is on the convex side of the plate, on which gauges $5 \mathrm{i}$ and $6 \mathrm{i}$ are mounted. These differences obviously are reflected in the gauge readings of each point and make it impossible to get a one-to-one comparison between gauges that have the same span coordinates but are on different plates. The span stresses as calculated from gauges $5 \mathrm{i}$ and $6 \mathrm{i}$ are shown in Fig. 5.2. In examining the stress from the pressure load, there is an abrupt shift between the readings for pressure loads of 172.4 MPa (25 psi) and 206.8 MPa (30 psi). This was the only point that showed such an abrupt shift. Had this change resulted from something happening in the plate structure, a similar abrupt change would have occurred in gauges $1 \mathrm{i}, 2 \mathrm{i}, 3 \mathrm{i}$, and $4 \mathrm{i}$ during the pressure-only load, but such a change was not evident. The abrupt change appears more likely to have occurred because of an errant contact resistance change that would cause a shift in the readings of the strain indicator for that channel. This is not an unusual effect to experience in strain gauge work. However, independent of this abrupt shift, the relation of the primary and secondary stress on plate failure as described with gauges 50 and 60 is repeated in the information from gauges $5 i$ and $6 i$. 
Table 5.1. Corrected strain values and stress calculations for test at $68.9 \mathrm{kPa}$ (10 psi)

\begin{tabular}{|c|c|c|c|c|c|c|}
\hline \multirow[b]{2}{*}{ Channel } & \multicolumn{3}{|c|}{ Strain, in microstrain } & \multicolumn{3}{|c|}{ Stress, in MPa (psi) } \\
\hline & $\begin{array}{c}\text { Pressure } \\
\text { only }\end{array}$ & $\begin{array}{l}\text { Thermal } \\
\text { load only }\end{array}$ & $\begin{array}{l}\text { Pressure and } \\
\text { thermal load }\end{array}$ & $\begin{array}{c}\text { Pressure } \\
\text { only }\end{array}$ & $\begin{array}{l}\text { Thermal } \\
\text { load only }\end{array}$ & $\begin{array}{l}\text { Pressure and } \\
\text { thermal load }\end{array}$ \\
\hline \multicolumn{7}{|c|}{ Box 1} \\
\hline 1 & -94 & -260 & -357 & $-7.39(-1072)$ & $-29.46(-4273)$ & $-36.69(-5321)$ \\
\hline 2 & -7 & -386 & -377 & $-2.85(-413)$ & $-36.04(-5227)$ & $-37.73(-5473)$ \\
\hline 3 & 174 & -107 & 63 & 13.09 (1899) & $-20.92(-3035)$ & $-7.94(-1152)$ \\
\hline 4 & -11 & -520 & -520 & $3.43(489)$ & $-42.55(-6171)$ & $-38.40(-5569)$ \\
\hline 5 & -120 & -331 & -452 & $-9.22(-1337)$ & $-34.10(-4946)$ & $-43.13(-6255)$ \\
\hline 6 & 0 & -353 & -342 & $-2.95(-428)$ & $-35.25(-5113)$ & $-38.38(-5422)$ \\
\hline 7 & -141 & -197 & -325 & $-10.07(-1460)$ & $-20.96(-3040)$ & $-29.98(-4348)$ \\
\hline 8 & 31 & -237 & -204 & $-1.08(-157)$ & $-23.05(-3343)$ & $-23.65(-3431)$ \\
\hline 9 & 145 & -174 & -18 & $11.07(1605)$ & $-21.13(-3065)$ & $-9.18(-1331)$ \\
\hline 10 & -3 & -316 & -317 & $3.33(483)$ & $-28.55(-4141)$ & $-24.79(-3596)$ \\
\hline \multicolumn{7}{|c|}{ Box 2} \\
\hline 1 & -294 & -137 & -290 & $-12.47(-1809)$ & $-17.06(-2475)$ & $-28.67(-4158)$ \\
\hline 2 & 7 & -266 & -260 & $-3.64(-528)$ & $-23.80(-3452)$ & $-27.10(-3930)$ \\
\hline
\end{tabular}

${ }^{a}$ For box 1 , channels $1-6$, thermal load $=24^{\circ} \mathrm{C}\left(43^{\circ} \mathrm{F}\right)$. For box 1 , channels $7-10$ and box 2 , channels $1-2$, thermal load $=14^{\circ} \mathrm{C}\left(26^{\circ} \mathrm{F}\right)$. 
Table 5.2. Corrected strain values and stress calculations for test at $137.9 \mathrm{kPa}$ (20 psi)

\begin{tabular}{|c|c|c|c|c|c|c|}
\hline \multirow[b]{2}{*}{ Channel } & \multicolumn{3}{|c|}{ Strain, in microstrain } & \multicolumn{3}{|c|}{ Stress, in MPa (psi) } \\
\hline & $\begin{array}{c}\text { Pressure } \\
\text { only }\end{array}$ & $\begin{array}{l}\text { Thermal } \\
\text { load only }\end{array}$ & $\begin{array}{l}\text { Pressure and } \\
\text { thermal load }\end{array}$ & $\begin{array}{l}\text { Pressure } \\
\text { only }\end{array}$ & $\begin{array}{l}\text { Thermal } \\
\text { load only }\end{array}$ & $\begin{array}{l}\text { Pressure and } \\
\text { thermal load }\end{array}$ \\
\hline \multicolumn{7}{|c|}{ Box 1} \\
\hline 1 & -201 & -255 & -550 & $-15.81(-2293)$ & $-28.61(-4149)$ & $-51.10(-7411)$ \\
\hline 2 & -15 & -367 & -360 & $-6.09(-884)$ & $-34.46(-4998)$ & $-41.17(-5971)$ \\
\hline 3 & 336 & -109 & 335 & $25.27(3665)$ & $-21.06(-3054)$ & $12.98(1882)$ \\
\hline 4 & -22 & -516 & -519 & $6.57(953)$ & $-42.31(-6137)$ & $-31.63(-4588)$ \\
\hline 5 & -241 & -328 & -635 & $-18.54(-2689)$ & $-33.67(-4884)$ & $-56.85(-8245)$ \\
\hline 6 & -1 & -345 & -328 & $-6.00(-870)$ & $-34.56(-5013)$ & $-40.80(-5918)$ \\
\hline 7 & -264 & -198 & -432 & $-18.90(-2742)$ & $-21.04(-3051)$ & $-37.31(-5412)$ \\
\hline 8 & 56 & -237 & -168 & $-2.21(-320)$ & $-23.07(-3346)$ & $-23.52(-3412)$ \\
\hline 9 & 300 & -175 & 218 & $22.77(3303)$ & $-21.26(-3083)$ & $8.96(1229)$ \\
\hline 10 & -11 & -318 & -317 & $6.53(947)$ & $-28.73(-4167)$ & $-18.99(-2754)$ \\
\hline \multicolumn{7}{|c|}{ Box 2} \\
\hline 1 & -294 & -134 & -409 & $-22.41(-3250)$ & $-16.81(-2438)$ & $-37.86(-5491)$ \\
\hline 2 & 7 & -265 & -262 & $-6.69(-970)$ & $-23.65(-3430)$ & $-30.18(-4377)$ \\
\hline
\end{tabular}

${ }^{a}$ For box 1 , channels $1-6$, thermal load $=24^{\circ} \mathrm{C}\left(43^{\circ} \mathrm{F}\right)$. For box 1 , channels $7-10$ and box 2 , channels $1-2$, thermal load $=14^{\circ} \mathrm{C}\left(26^{\circ} \mathrm{F}\right)$. 
Table 5.3. Corrected strain values and stress calculations for test at $172.4 \mathrm{kPa}$ ( $25 \mathrm{psi}$ )

\begin{tabular}{|c|c|c|c|c|c|c|}
\hline \multirow[b]{2}{*}{ Channel } & \multicolumn{3}{|c|}{ Strain, in microstrain } & \multicolumn{3}{|c|}{ Stress, in $\mathrm{MPa}$ (psi) } \\
\hline & $\begin{array}{l}\text { Pressure } \\
\text { only }\end{array}$ & $\begin{array}{l}\text { Thermal } \\
\text { load only }\end{array}$ & $\begin{array}{l}\text { Pressure and } \\
\text { thermal load }\end{array}$ & $\begin{array}{c}\text { Pressure } \\
\text { only }\end{array}$ & $\begin{array}{l}\text { Thermal } \\
\text { load only }\end{array}$ & $\begin{array}{l}\text { Pressure and } \\
\text { thermal load }\end{array}$ \\
\hline \multicolumn{7}{|c|}{ Box 1} \\
\hline 1 & -249 & -255 & -553 & $-15.81(-2293)$ & $-28.61(-4149)$ & $-51.10(-7411)$ \\
\hline 2 & -18 & -367 & -360 & $-6.09(-884)$ & $-34.46(-4998)$ & $-41.17(-5971)$ \\
\hline 3 & 423 & -109 & 332 & $25.27(3665)$ & $-21.06(-3054)$ & $12.98(1882)$ \\
\hline 4 & -27 & -516 & -510 & $6.57(953)$ & $-42.31(-6137)$ & $-31.63(-4588)$ \\
\hline 5 & -300 & -328 & -692 & $-18.54(-2689)$ & $-33.67(-4884)$ & $-56.85(-8245)$ \\
\hline 6 & 0 & -345 & -324 & $-6.00(-870)$ & $-34.56(-5013)$ & $-40.80(-5918)$ \\
\hline 7 & -333 & -198 & -486 & $-18.90(-2742)$ & $-21.04(-3051)$ & $-37.31(-5412)$ \\
\hline 8 & 74 & -237 & -221 & $-2.21(-320)$ & $-23.07(-3346)$ & $-23.52(-3412)$ \\
\hline 9 & 374 & -175 & 288 & $22.77(3303)$ & $-21.26(-3083)$ & 8.96 (1299) \\
\hline 10 & -11 & -318 & -383 & $6.53(947)$ & $-28.73(-4167)$ & $-18.99(-2754)$ \\
\hline \multicolumn{7}{|c|}{ Box 2} \\
\hline 1 & -376 & -134 & -455 & $-22.41(-3250)$ & $-16.81(-2438)$ & $-37.86(-5491)$ \\
\hline 2 & 8 & -265 & -270 & $-6.69(-970)$ & $-23.65(-3430)$ & $-30.18(-4377)$ \\
\hline
\end{tabular}

${ }^{a}$ For box 1 , channels $1-6$, thermal load $=24^{\circ} \mathrm{C}\left(43^{\circ} \mathrm{F}\right)$. For box 1 , channels $7-10$ and box 2 , channels $1-2$, thermal load $=17^{\circ} \mathrm{C}\left(30^{\circ} \mathrm{F}\right)$. 
Table 5.4. Corrected strain values and stress calculations for test at $206.8 \mathrm{kPa}$ (30 psi)

\begin{tabular}{|c|c|c|c|c|c|c|}
\hline \multirow[b]{2}{*}{ Channel } & \multicolumn{3}{|c|}{ Strain, in microstrain } & \multicolumn{3}{|c|}{ Stress, in MPa (psi) } \\
\hline & $\begin{array}{c}\text { Pressure } \\
\text { only }\end{array}$ & $\begin{array}{l}\text { Thermal } \\
\text { load only }\end{array}$ & $\begin{array}{l}\text { Pressure and } \\
\text { thermal load }\end{array}$ & $\begin{array}{c}\text { Pressure } \\
\text { only }\end{array}$ & $\begin{array}{l}\text { Thermal } \\
\text { load only }\end{array}$ & $\begin{array}{l}\text { Pressure and } \\
\text { thermal load }\end{array}$ \\
\hline \multicolumn{7}{|c|}{ Box 1} \\
\hline 1 & -335 & -254 & -565 & $-26.44(-3835)$ & $-28.12(-4078)$ & $-51.98(-7539)$ \\
\hline 2 & -29 & -350 & -349 & $-10.46(-1517$ & $-33.13(-4805)$ & $-40.69(-5902)$ \\
\hline 3 & 487 & -126 & 376 & $36.45(5287)$ & $-21.82(-3165)$ & $16.64(2414)$ \\
\hline 4 & -39 & -494 & -498 & $8.98(1302$ & $-41.04(-5953)$ & $-29.01(-4208)$ \\
\hline 5 & -343 & -326 & -703 & $-26.56(-3853)$ & $-33.18(-4812)$ & $-61.71(-8951)$ \\
\hline 6 & -9 & -331 & -314 & $-9.12(-1323$ & $-33.44(-4850)$ & $-41.39(-6004)$ \\
\hline 7 & -357 & -199 & -485 & $-25.43(-3689)$ & $-20.67(-2998)$ & $-42.56(-6173)$ \\
\hline 8 & 81 & -219 & -216 & $-2.55(-370)$ & $-21.71(-3149)$ & $-28.51(-4135)$ \\
\hline 9 & 491 & -175 & 297 & $37.24(5402)$ & $-21.24(-3080)$ & $12.98(1883)$ \\
\hline 10 & -19 & -317 & -400 & $10.61(1539)$ & $-28.65(-4156)$ & $-23.43(-3398)$ \\
\hline \multicolumn{7}{|c|}{ Box 2} \\
\hline 1 & -329 & -139 & -550 & $-25.28(-3637)$ & $-17.12(-2438)$ & $-48.73(-7068)$ \\
\hline 2 & 8 & -262 & -264 & $-7.47(-1084)$ & $-23.54(-3414)$ & $-33.80(-4902)$ \\
\hline
\end{tabular}

${ }^{a}$ For box 1 , channels $1-6$, thermal load $=24^{\circ} \mathrm{C}\left(43^{\circ} \mathrm{F}\right)$. For box 1 , channels $7-10$ and box 2 , channels $1-2$, thermal load $=14^{\circ} \mathrm{C}\left(26^{\circ} \mathrm{F}\right)$. 
Table 5.5. Corrected strain values and stress calculations for test at $275.8 \mathrm{kPa}$ (40 psi)

\begin{tabular}{|c|c|c|c|c|c|c|}
\hline \multirow[b]{2}{*}{ Channel } & \multicolumn{3}{|c|}{ Strain, in microstrain } & \multicolumn{3}{|c|}{ Stress, in MPa (psi) } \\
\hline & $\begin{array}{l}\text { Pressure } \\
\text { only }\end{array}$ & $\begin{array}{c}\text { Thermal } \\
\text { load only }\end{array}$ & $\begin{array}{l}\text { Pressure and } \\
\text { thermal load }\end{array}$ & $\begin{array}{c}\text { Pressure } \\
\text { only }\end{array}$ & $\begin{array}{l}\text { Thermal } \\
\text { load only }\end{array}$ & $\begin{array}{l}\text { Pressure and } \\
\text { thermal load }\end{array}$ \\
\hline \multicolumn{7}{|c|}{ Box 1} \\
\hline 1 & -375 & -262 & -644 & $-28.93(-4196)$ & $-28.53(-4138)$ & $-57.84(-8390)$ \\
\hline 2 & -5 & -342 & -341 & $-9.60(-1393)$ & $-32.72(-4744)$ & $-42.02(-6095)$ \\
\hline 3 & 502 & -131 & 531 & $38.26(5550)$ & $-22.10(-3206)$ & $28.65(4155)$ \\
\hline 4 & -12 & -490 & -494 & $11.42(1656$ & $-40.86(-5926)$ & $-24.90(-3611)$ \\
\hline 5 & -366 & -333 & -742 & $-27.79(-4031)$ & $-33.71(-4890)$ & $-64.39(-9340)$ \\
\hline 6 & 13 & -331 & -301 & $-8.00(-1160$ & $-33.61(-4875)$ & $-41.36(-5999)$ \\
\hline 7 & -368 & -210 & -504 & $-26.30(-3815)$ & $-21.73(-3152)$ & $-44.17(-6406)$ \\
\hline 8 & 80 & -228 & -222 & $-2.90(-421)$ & $-22.68(-3289)$ & $-29.44(-4270)$ \\
\hline 9 & 517 & -179 & 428 & $39.24(5692)$ & $-21.44(-3110)$ & $22.87(3317)$ \\
\hline 10 & -19 & -313 & -407 & $11.24(1631)$ & $-28.44(-4125)$ & $-20.74(-3008)$ \\
\hline \multicolumn{7}{|c|}{ Box 2} \\
\hline 1 & -449 & -147 & -676 & $-34.24(-4967)$ & $-17.88(-2593)$ & $-58.55(-8493)$ \\
\hline 2 & 10 & -268 & -270 & $-10.27(-1489)$ & $-24.20(-3510)$ & $-33.80(-5418)$ \\
\hline
\end{tabular}

For box 1 , channels $1-6$, thermal load $=24^{\circ} \mathrm{C}\left(43^{\circ} \mathrm{F}\right)$. For box 1 , channels $7-10$ and box 2 , channels $1-2$, thermal load $=14^{\circ} \mathrm{C}\left(26^{\circ} \mathrm{F}\right)$. 
Table 5.6. Corrected strain values and stress calculations for test at $344.7 \mathrm{kPa}$ (50 psi)

\begin{tabular}{|c|c|c|c|c|c|c|}
\hline \multirow[b]{2}{*}{ Channel } & \multicolumn{3}{|c|}{ Strain, in microstrain } & \multicolumn{3}{|c|}{ Stress, in $\mathrm{MPa}$ (psi) } \\
\hline & $\begin{array}{c}\text { Pressure } \\
\text { only }\end{array}$ & $\begin{array}{l}\text { Thermal } \\
\text { load only }\end{array}$ & $\begin{array}{l}\text { Pressure and } \\
\text { thermal load }\end{array}$ & $\begin{array}{c}\text { Pressure } \\
\text { only }\end{array}$ & $\begin{array}{l}\text { Thermal } \\
\text { load only }\end{array}$ & $\begin{array}{l}\text { Pressure and } \\
\text { thermal load }\end{array}$ \\
\hline \multicolumn{7}{|c|}{ Box 1} \\
\hline 1 & -510 & -284 & -350 & $-39.25(-5693)$ & $-30.22(-4383)$ & Note $b$ \\
\hline 2 & -3 & -342 & -296 & $-12.77(-1852)$ & $-33.25(-4822)$ & \\
\hline 3 & 569 & -134 & 1231 & $43.56(6318)$ & $-22.16(-3214)$ & \\
\hline 4 & -6 & -483 & -506 & 13.53 (1962) & $-40.39(-5859)$ & \\
\hline 5 & -402 & -333 & -265 & $-30.38(-4407)$ & $-33.59(-4872)$ & \\
\hline 6 & 20 & -326 & -302 & $-8.34(-1210)$ & $-33.22(-4819)$ & \\
\hline 7 & -391 & -172 & -7136 & $-28.07(-4071)$ & $-18.59(-2697)$ & \\
\hline 8 & 80 & -219 & 238 & $-3.47(-503)$ & $-21.05(-3053)$ & \\
\hline 9 & 722 & -158 & 7630 & 54.69 (7933) & $-19.86(-2880)$ & \\
\hline 10 & -31 & -314 & -387 & $15.37(2229)$ & $-28.00(-4061)$ & \\
\hline \multicolumn{7}{|c|}{ Box 2} \\
\hline 1 & -528 & -153 & -5342 & $-40.28(-5843)$ & $-18.14(-2631)$ & \\
\hline 2 & 11 & -260 & -98 & $-12.13(-1760)$ & $-23.73(-3442)$ & \\
\hline
\end{tabular}

${ }^{a}$ For box 1 , channels $1-6$, thermal load $=24^{\circ} \mathrm{C}\left(43^{\circ} \mathrm{F}\right)$. For box 1 , channels $7-10$ and box 2 , channels $1-2$, thermal load $=14^{\circ} \mathrm{C}\left(26^{\circ} \mathrm{F}\right)$.

${ }^{b}$ Stress calculations for the plate with the combined load of pressure and temperature are not shown because the plates failed when this load was applied. 


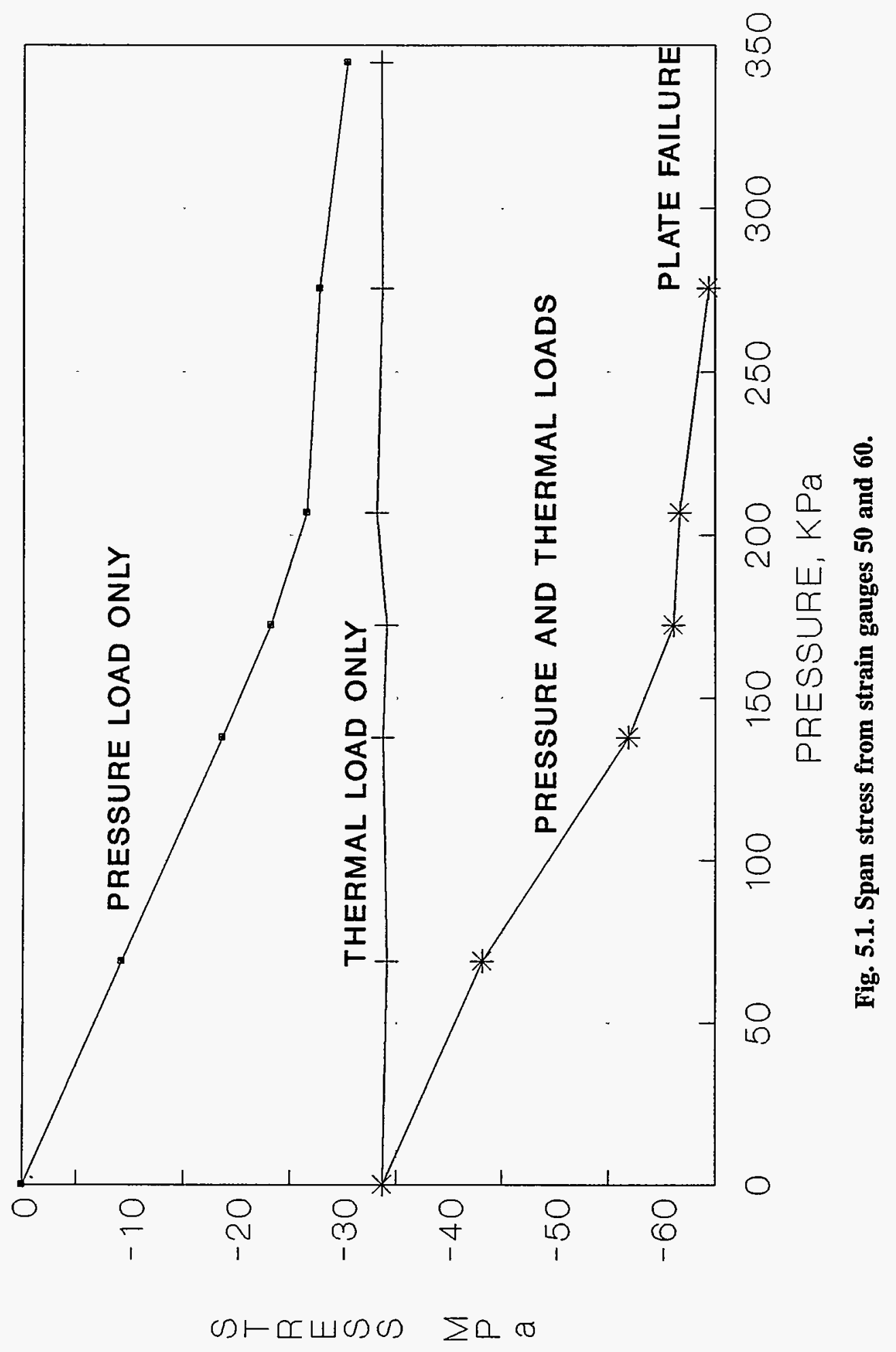




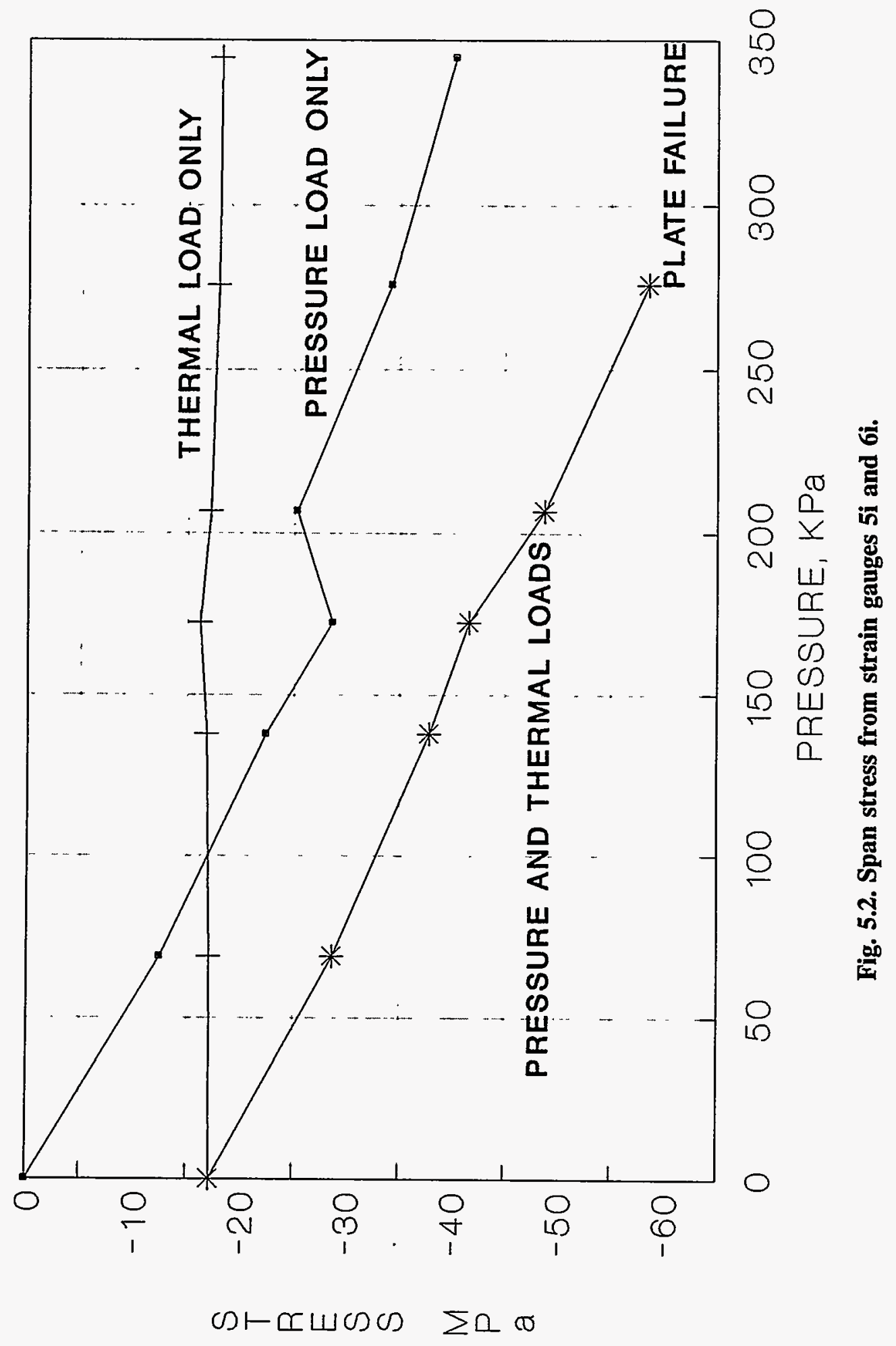


The stresses in the span direction as calculated from the gauge pairs 10,20 and $1 \mathrm{i}, 2 \mathrm{i}$ are shown in Figs. 5.3 and 5.4. These points are close to the inside support boundary. The results show the same effect as summarized from the previous analysis using gauge pairs 50,60 and 5i, $6 \mathrm{i}$.

The stresses in the span direction as calculated from the gauge pairs 30,40 and $3 i, 4 i$ are shown in Figs. 5.5 and 5.6. These points are located where the maximum deflections of the involute plates were anticipated. It is of interest to note that the stresses at these points from the thermal load tend to reduce the stresses from the pressure load. These points actually had larger strains in the final deformed shape after failure than did the points near the boundaries. It appears that "plastic hinges" formed on the boundaries and resulted in the central portion of the plate's reacting more like a plate with pinned boundaries with very large strains occurring in the central part of the plates.

If only the pressure loads, which are equivalent to coolant velocity flow loads in the reactor, are considered, all of the stresses at the test points were below yield stress up through a pressure load of $344.7 \mathrm{MPa}(50 \mathrm{psi})$. This pressure is equivalent to a coolant flow velocity of $36.0 \mathrm{~m} / \mathrm{s}$ (118 fps). However, when the thermal load was included in the plate load, failure did occur. 


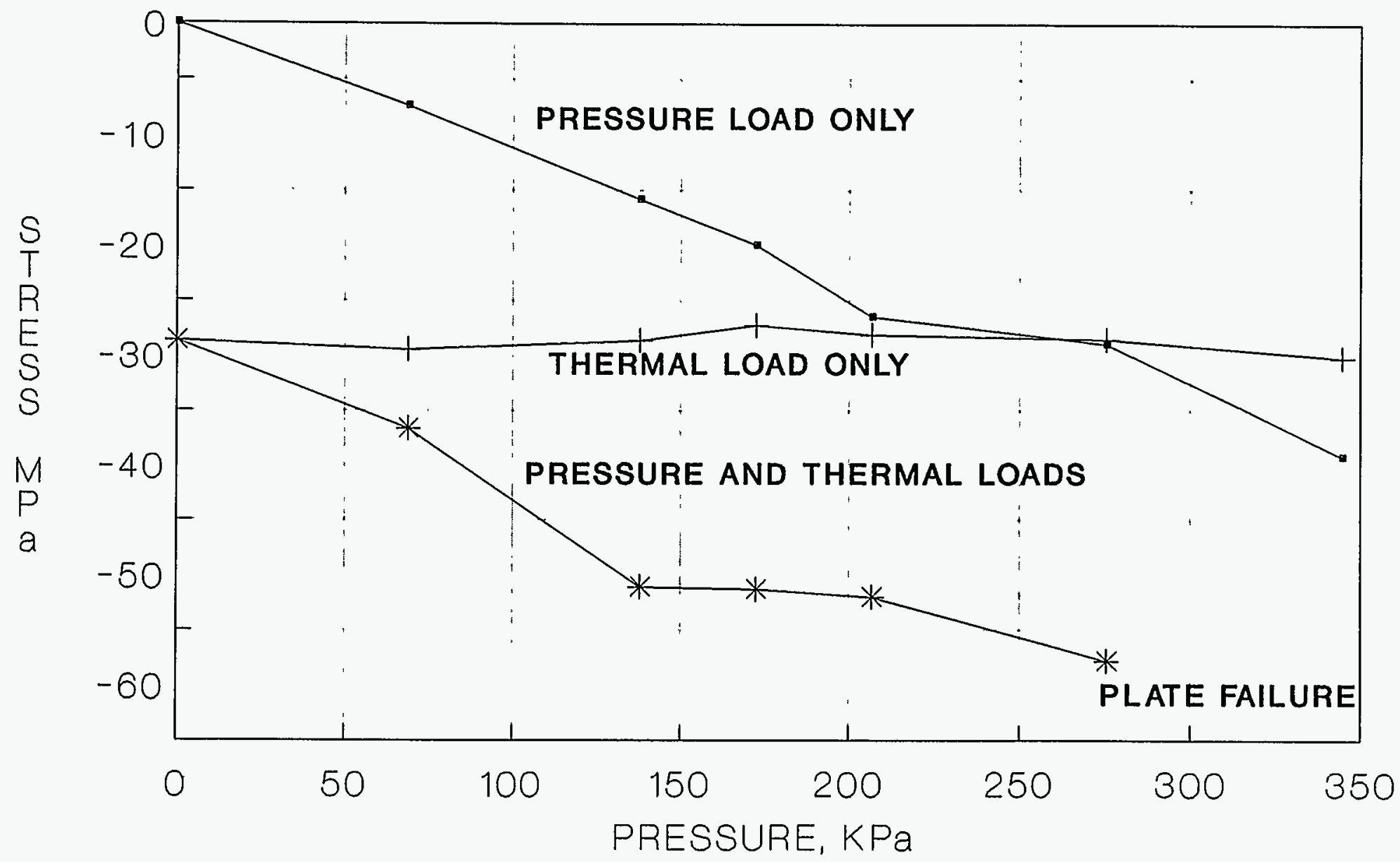

Fig. 5.3. Span stress from strain gauges 10 and 20 . 


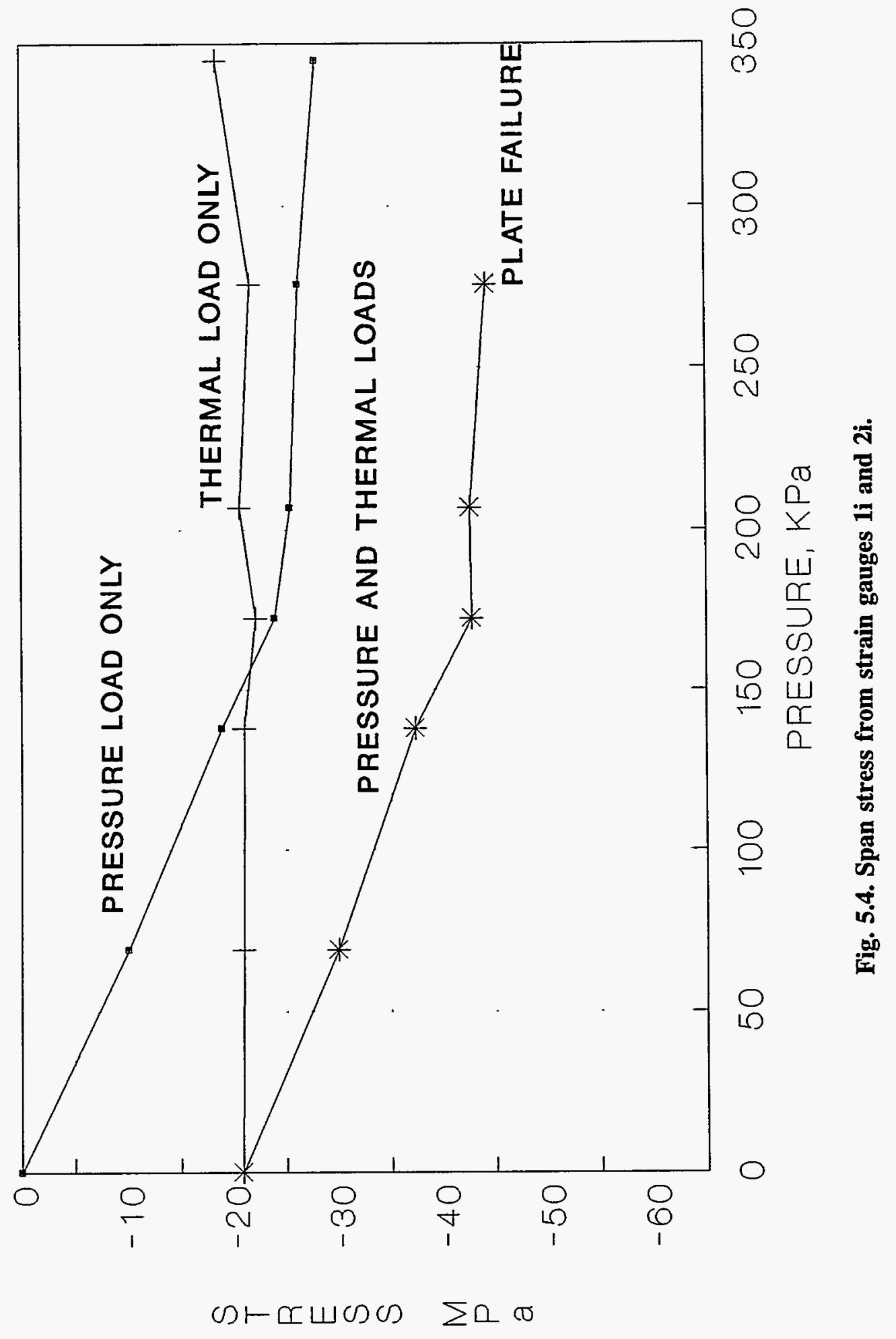




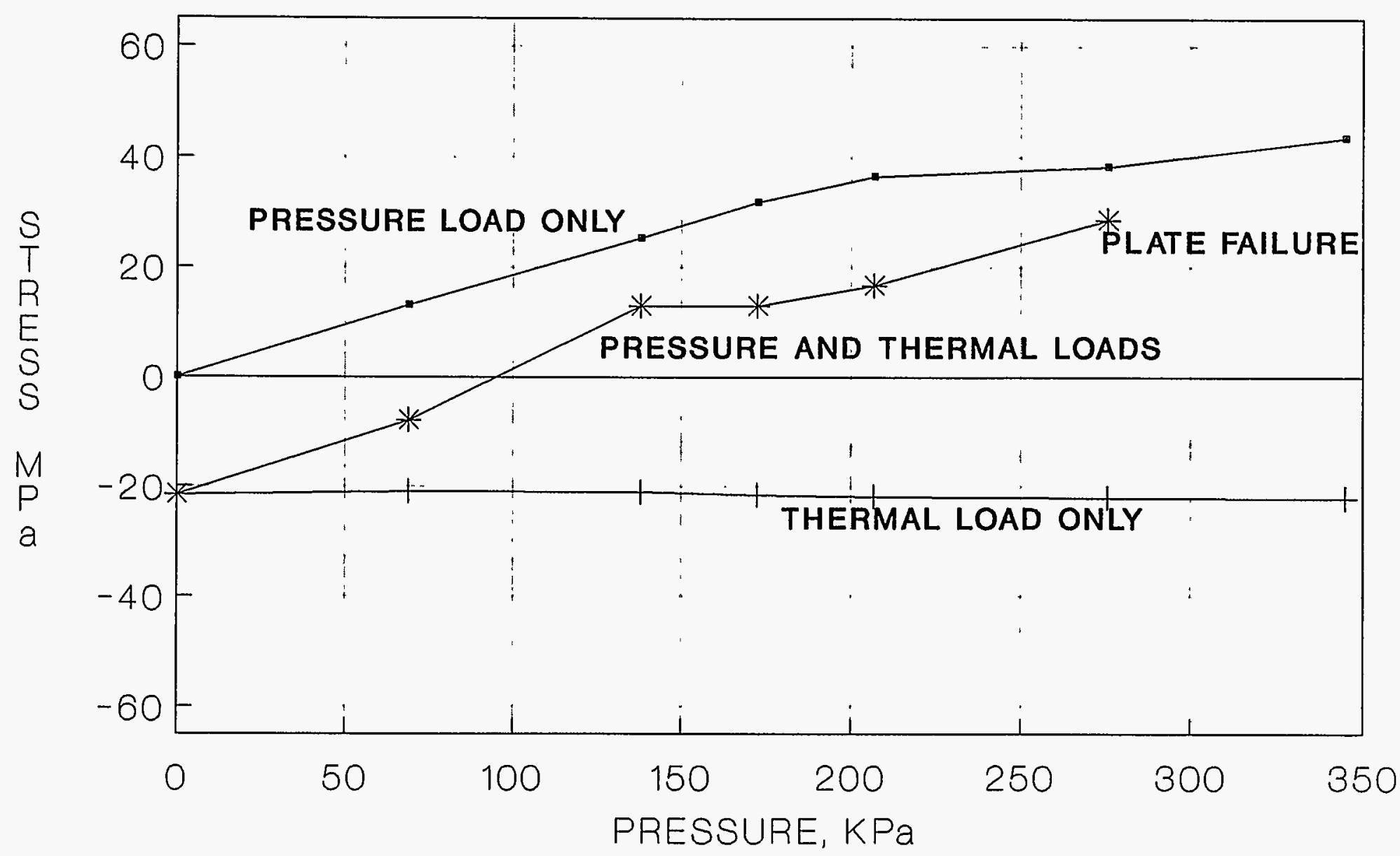

Fig. 5.5. Span stress from strain gauges 30 and 40 . 


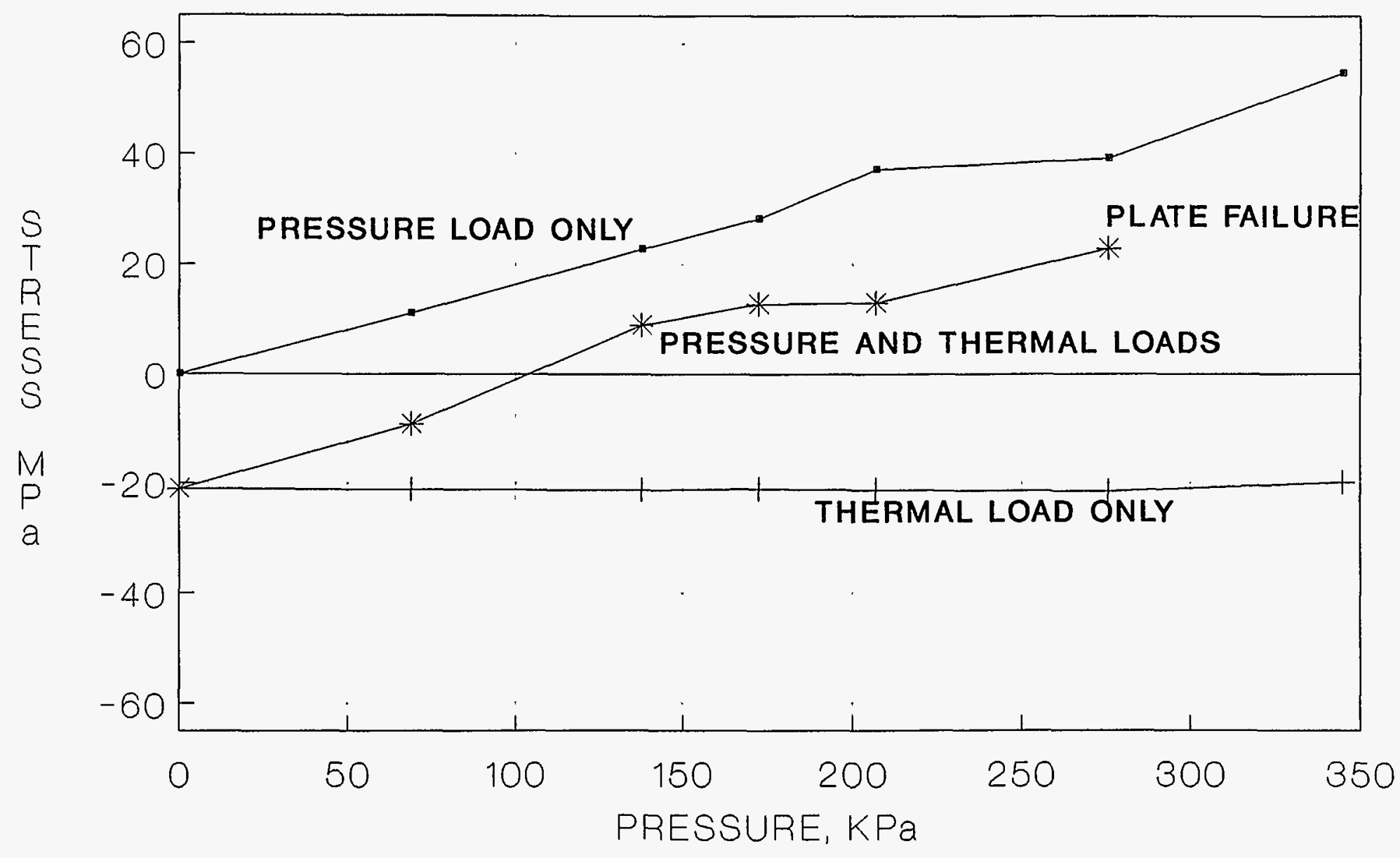

Fig. 5.6. Span stress from strain gauges $3 i$ and $4 i$. 


\section{CONCLUSIONS}

The purpose of this experiment was to examine the rationale of weighing the secondary (thermal) stresses, which result from the fuel reactions in the plates, less than the primary (pressure) stresses, which are related to the coolant flow velocity between the plates. These tests indicate that, for this application of thin aluminum fuel plates, cooled through narrow cooling channels on both sides of a plate, the primary and secondary stresses should be weighted the same.

These structural tests with the proposed ANS fuel plates are the last ones scheduled, since the ANS project is ending; therefore, for possible future reference, a summary status statement for this work is offered.

1. For the type of fuel plates proposed for ANS, there was no evidence of a collapse flow velocity as proposed by Miller $^{7}$ in a coolant velocity range from 0 to $50 \mathrm{~m} / \mathrm{s}^{1.2 .5}$

2. There was no evidence of any significant plate flutter in the proposed plates with a coolant velocity range from 0 to $35 \mathrm{~m} / \mathrm{s} .{ }^{1,2,5}$

3. The most critical design variable in the plates is the stress value, and, as reported herein, the stresses produced from thermal loads should be given the same weight as the stresses produced from the flow loads. ${ }^{1-3,5}$

4. The coolant flow load on the plates can be determined using the techniques reported in Ref. 3 with the load variation reported in Ref. 5. Having defined the flow load, the plate deformation and stress values can be approximately calculated using standard solution schemes such as numerical or analytical techniques.

5. The structural deformation and stress values of the plates resulting from thermal loads can be approximated using the standard solution schemes as noted above, if a reasonable temperature distribution in the plates is available.

6. Calculations using a creep model for the ANS plates indicate that creep is not a limiting variable within the coolant flow rates and temperatures considered for the ANS Project. ${ }^{4}$ 


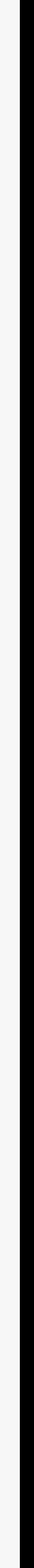




\section{REFERENCES}

1. W. F. Swinson et al., Fuel Plate Stability Experiments and Analysis for the Advanced Neutron Source, ORNL/TM-12353, Martin Marietta Energy Systems, Inc., Oak Ridge Natl. Lab., May 1993.

2. W. F. Swinson et al., Follow-Up Fuel Plate Stability Experiments and Analyses for the Advanced Neutron Source, ORNL/TM-12629, Martin Marietta Energy Systems, Inc., Oak Ridge Natl. Lab., November 1993.

3. W. F. Swinson et al., An Examination of the Elastic Structural Response of the Advanced Neutron Source Fuel Plates, ORNL/TM-12712, Martin Marietta Energy Systems, Inc., Oak Ridge Natl. Lab., September 1994.

4. W. F. Swinson and G. T. Yahr, Creep Analysis of Fuel Plates for the Advanced Neutron Source, ORNL/TM-12788, Martin Marietta Energy Systems, Inc., Oak Ridge Natl. Lab., August 1994.

5. W. F. Swinson et al., Circular Arc Fuel Plate Stability Experiments and Analyses for the Advanced Neutron Source, ORNL/TM-12977, Lockheed Martin Energy Systems, Inc., Oak Ridge Natl. Lab., August 1995.

6. ASME Boiler and Pressure Vessel Committee, ASME Boiler and Pressure Vessel Code, Section III: Division I, American Society of Mechanical Engineers, New York, 1992.

7. D. R. Miller, "Critical Flow Velocities for Collapse of Reactor Parallel Plate Fuel Assemblies," Trans. ASME 82, 83 (1960). 


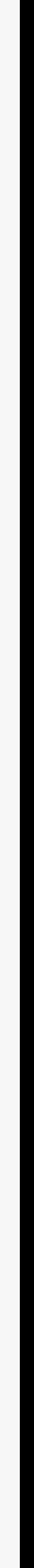




\section{INTERNAL DISTRIBUTION}

1. B. R. Appleton

2. R. L. Battiste

3. D. K. Felde

4. R. G. Gilliland

5. R. C. Gwaltney

6. W. R. Hendrick

7-10. R. L. Johnson

11. C. R. Luttrell

12. D. L. Selby
13-17. W. F. Swinson

18. C. D. West

19. G. T. Yahr

20. ORNL Patent Office

21-22. Central Research Library

23. Y-12 Technical Library, Document Reference Section

24-25. Laboratory Record Dept.

26. Laboratory Records, RC

\section{EXTERNAL DISTRIBUTION}

27. U.S. Department of Energy, ANS Project Office, Oak Ridge Operations Office, FEDC, MS-8218, P.O. Box 2009, Oak Ridge, TN 37831-8218

28-29. Office of Scientific and Technical Information, P.O. Box 63, Oak Ridge, TN 37831 
